\title{
The smelting of copper in the third millennium cal BC Trentino, north-eastern Italy
}

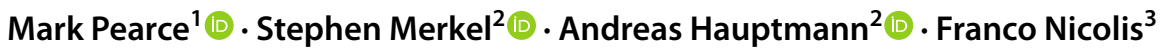

Received: 26 May 2021 / Accepted: 16 November 2021 / Published online: 23 December 2021

(c) The Author(s) 2021

\begin{abstract}
This paper presents observations and analyses on seven slag pieces from two third-millennium cal BC (Late Copper Age/ Early Bronze Age) rock shelters in the Trentino, north-eastern Italy: La Vela di Valbusa and the Riparo di Monte Terlago. We review previous work on contemporary slags from the region and show that the smelting did not follow the well-known 'Timna', 'Eibner' or so-called 'Chalcolithic' copper smelting processes. We show that ethnographic accounts of copper smelting in the Himalayas (Sikkim and Nepal) illuminate the smelting process, in particular the lack of preliminary roasting or ore beneficiation by washing, the use of slags as fluxes for the first smelt (matte smelting) and the use of wooden (?) implements to lift the hot slags from the furnace during the smelt. The rock inclusions in the slag are consistent with an ore origin from mines at Calceranica or Vetriolo, as previously reported in the literature.
\end{abstract}

Keywords Trentino $\cdot$ Copper smelting $\cdot$ Slag $\cdot$ Fluxes $\cdot$ Ethnography $\cdot$ Archaeometallurgy

\section{Introduction}

As a by-product of smelting, metallurgical slags represent an ideal record of the technological processes undertaken in producing metal from ore, and they have long been seen as such (review in Hauptmann 2014, 2020: 222-280). Slags are artificial and are the result of human choice and furnace firing conditions, but two important aspects should be remembered (1) that they represent a specific moment in the smelting process - when the slag solidified-i.e. was 'frozen in time', and (2) that the primary aim of the metalworker is to make metal, not slags.

As will be seen in this paper, the interpretation of slags is not always self-evident, and we suggest that ethnographic accounts of smelting can provide useful analogies, illustrations of possible ways in which metal may be smelted. One

Mark Pearce

mark.pearce@nottingham.ac.uk

1 Department of Classics and Archaeology, University of Nottingham, Nottingham NG7 2RD, UK

2 Deutsches Bergbau-Museum, Am Bergbaumuseum 31, 44791 Bochum, Germany

3 Ufficio Beni Archeologici, Soprintendenza per i Beni Culturali, Provincia autonoma di Trento, via Mantova 67, 38122 Trento, Italy such study which we have used with profit is Nils Anfinset's (2001), Social and technological aspects of mining, smelting and casting copper: an ethnoarchaeological study from Nepal. We shall call the process he describes the 'Himalayan' method as it is substantially the same as that observed by Blanford (1861) in Sikkim.

The south Alpine region of Trentino-Alto Adige/Südtirol, in northern Italy, has extensive evidence for prehistoric copper smelting, which is attested in two main periods (Perini 1989). The first phase, discussed in this paper, dates to the third millennium cal BC, corresponding to part of the Copper Age (CA; 3500-2200 cal BC) and Early Bronze Age (EBA; 2200-1650 cal BC). The dating of the second phase (Marzatico 1997; Pearce 2007: 73-81, 2020; Cierny 2008; Silvestri et al. 2019) is controversial: Pearce et al. (2020, 2021) have argued, on the basis of radiocarbon dates and the isotopic signal of Trentino copper in artefacts, that the second phase begins in the fifteenth, perhaps even the sixteenth, century cal $\mathrm{BC}$ and continues until the ninth century cal BC, i.e. from the Middle Bronze Age (MBA; $1650-1350$ cal BC) to the Early Iron Age (EIA; 950-390 cal BC), while Marzatico (2021) argues, on the basis of material culture at smelting sites, that it is limited to the Recent (RBA; 1350-1150 cal BC) and Final Bronze Ages (FBA; $1150-950 \mathrm{cal} \mathrm{BC})$. It is also not impossible that production continues between the two periods (Pearce et al. 2021: 
193-196; cf. Mottes et al. 2012). A number of CA and EBA sites are known (Fig. 1), and their main features are summarised in Table 1; bibliographies for their archaeological features are provided in the online resource (supplementary materials). Most of these sites are situated in the valley of the Adige/Etsch, particularly around Trento, with two hilltop sites in the Fersina valley ore district to the east (Montesei di Serso and Croz del Cius), and there is another cluster further north in the Adige/Etsch valley around Bressanone/Brixen. One recently discovered EBA site, Riparo di Monte Terlago, is located west of the Adige/Etsch valley, across the watershed in the Valley of the Lakes, which drains southwards into Lake Garda.

In this paper, we present observations and analyses on slags from two rock shelters in the Trentino: La Vela di Valbusa (late CA or EBA) and the Riparo di Monte Terlago (EBA).

The rock shelter of La Vela di Valbusa, in the Adige/ Etsch valley just north of Trento, was discovered by local enthusiasts in 1969 as a result of aggregates quarrying for motorway construction and recorded in an emergency rescue excavation (Fasani 1990). Unfortunately, much of the stratigraphy was damaged by the amateurs, but underneath an
EBA tumulus and inhumation burial, close to the rock face, a spread of some hundreds of slag pieces was found. Because of the nature of the excavation, it is not clear how much of the slag was recovered, and it is therefore unfortunately impossible to quantify how much was originally present at the site. At the centre of this slag spread and overlying it, there was a roughly oval bowl-shaped area of baked clay associated with three tuyères (Fig. 2; Fasani 1990: 165-75); a further area of baked earth was found $4 \mathrm{~m}$ away, again associated with slag (Perini 1989: 378, Fig. 11); these areas are probably best interpreted as roasting beds. The tomb is dated to the Early Bronze Age, so providing a terminus ante or ad quem for the smelting activity (Fasani 1990: 175).

The Riparo (rock shelter) di Monte Terlago was discovered in 2009, at an altitude of c. $900 \mathrm{~m}$ a.s.l. in a calcareous breccia on the slopes of the Paganella massif, and has been excavated since 2010 (Dalmeri et al. 2011: 327). Slag was found in layers 8 and 9 (EBA and MBA), which were sealed between sterile layers (Dalmeri et al. 2011: 329); the slag presented in this paper comes from level 8; a radiocarbon date for layer 9 of 2470-2200 cal BC at $95.4 \%$ (LTL15090A: $3862 \pm 45$; calibration using OxCal 4.4: Bronk Ramsey 2009; Reimer et al. 2020), at the transition between
Fig. 1 (1) Grotte di Castel Corno; (2) San Rocco; (3) Acquaviva di Besenello; (4) Romagnano Loch; (5) Romagnano Maso Monache; (6) Romagnano Tof de la Val; (7) Romagnano Angeli; (8) Riparo del Santuario; (9) Montesei di Serso; (10) Croz del Cius; (11) La Vela di Valbusa; (12) Riparo Gaban; (13) Riparo Marchi; (14) Riparo di Monte Terlago; (15) Gudon/ Gufidaun, propr. Plank; (16) Tanzgasse; (17) Albes/Albeins, propr. Notflatscher; (18) Bressanone/Brixen Circonvallazione ovest; and (19) Millan/Milland

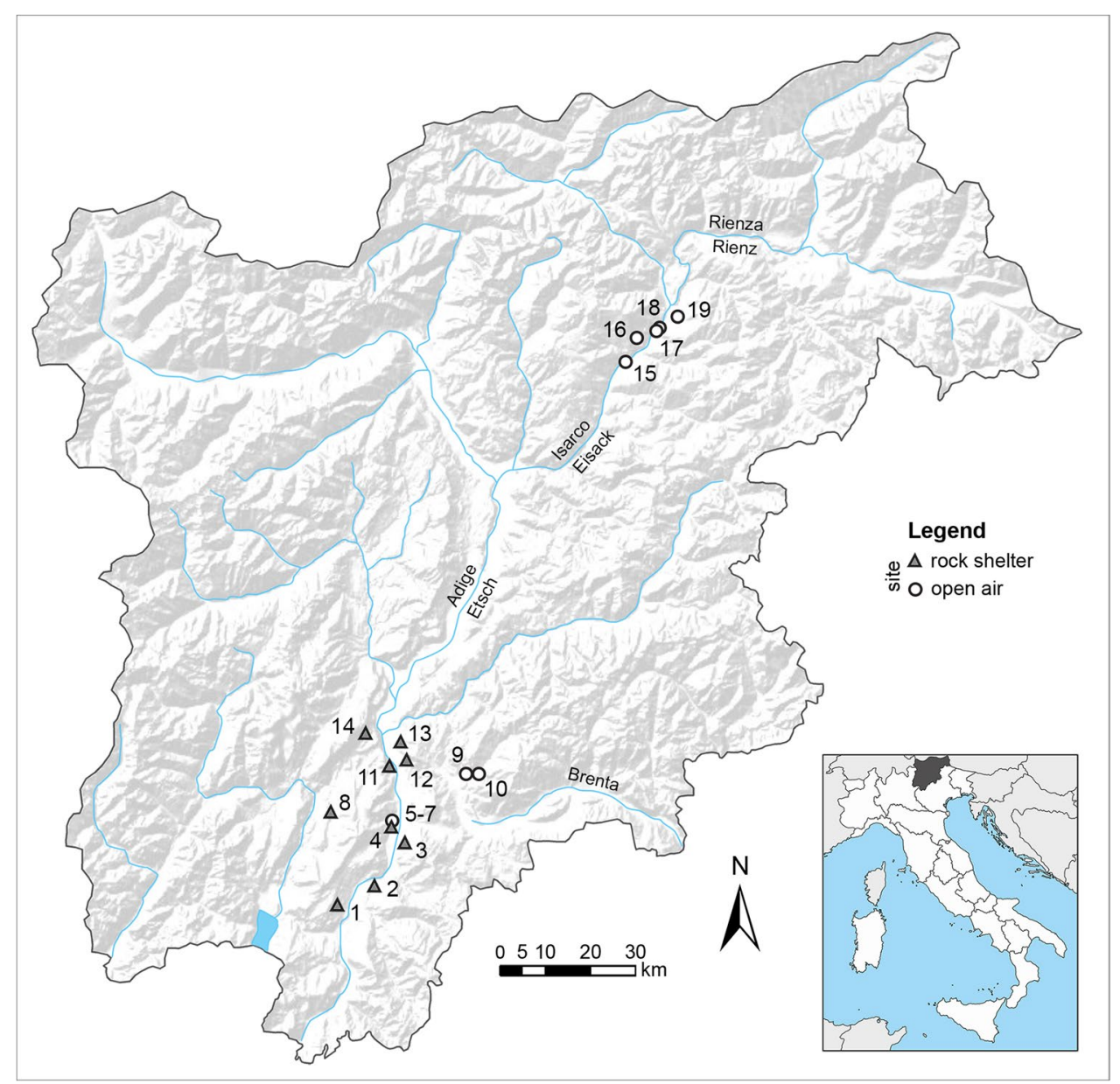




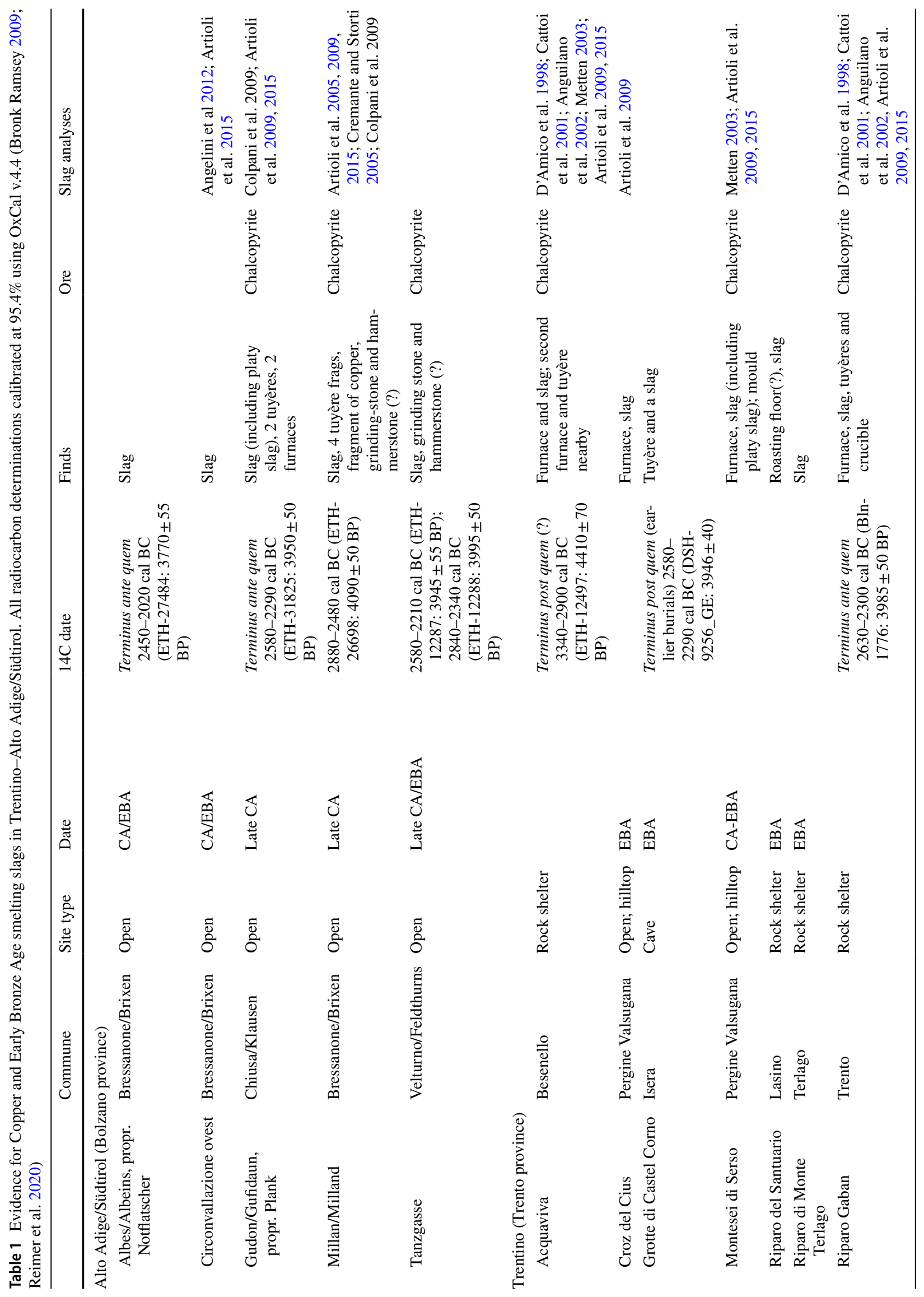




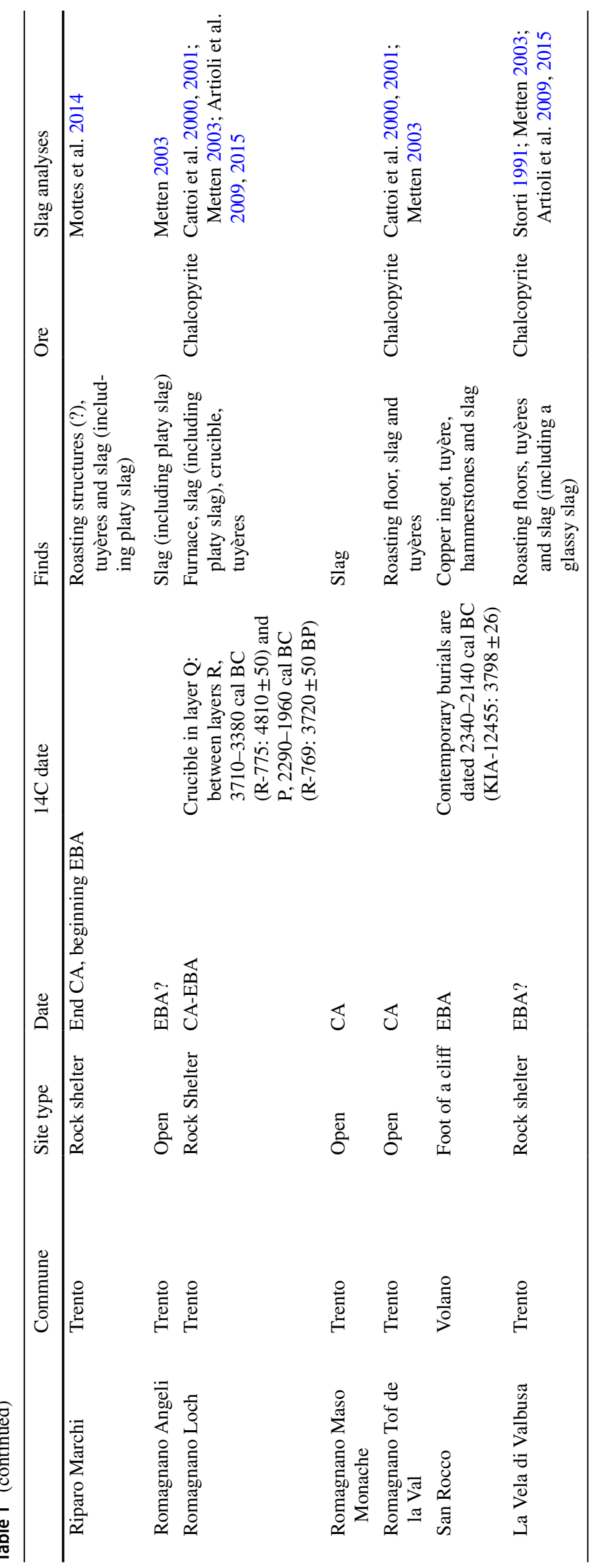




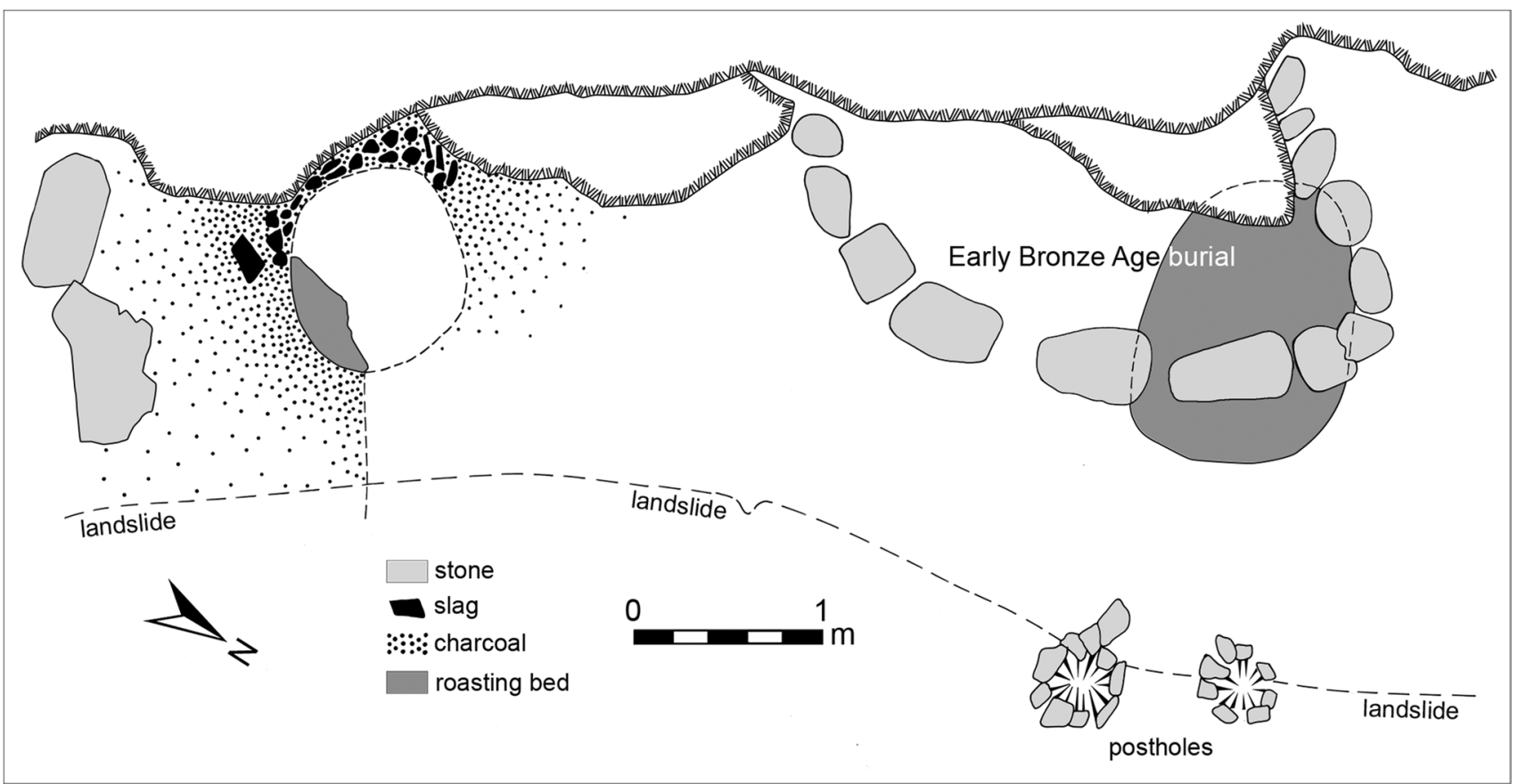

Fig. 2 Site plan of La Vela di Valbusa showing the two roasting beds, the larger one, which underlies the kerb of an EBA tumulus, overlay a large spread of slag (after Fasani 1990: Fig. 9 and Perini 1989: Fig. 11)

the Copper Age and the Bronze Age, provides a terminus post quem for layer 8 , which diagnostic pottery suggests dates to the EBA (Paolo Bellintani, pers. com. 28 Sept. 2016). Because of the small size of the test pit, it is not possible to quantify the amount of slag in the rock shelter, but it would seem that the excavated area is marginal to the focus of smelting activity, and no smelting facilities have been identified to date.

A number of models have been put forward for the smelting process in the Bronze Age of the Alps, and we shall briefly review these.

\section{The 'Eibner' roasting and smelting model}

As we shall see, interpretation of the technological process of smelting in the Alps has been strongly influenced by a model proposed by Clemens Eibner (1982), which in the 1990s replaced the 'Timna model' which had until then been the dominant paradigm for understanding prehistoric smelting processes. The 'Timna model' was based on the evidence for the Late Bronze Age (LBA)-EIA smelting of the largely oxidised sedimentary copper ore deposits of the Negev, which are rather different from the complex copper sulphides of Europe (Craddock 2009: 3-4). Eibner (1982) on the other hand interpreted the smelting process on the basis of the sixteenth-century AD account of Georgius Agricola (1912 [1556]), who documented the matte smelting of complex sulphides in the Erzgebirge between Saxony and Bohemia, describing copper ore roasting (1912 [1556]: 273-275, 279, 349-351) and copper smelting (1912 [1556]: 353-354, 374, 384-386, 388-390, 401-408). In Eibner's (1982) model, the ore was first roasted and then smelted; the resulting matte was then roasted and smelted to metallic copper (matte conversion).

\section{‘Free-silica' slags}

Another influential idea was introduced by Beno Rothenberg and Antonio Blanco-Freijeiro in 1981, in their interpretation of slags found in Huelva province, south-eastern Spain. They noted the presence of quartz inclusions in many LBA and Phoenician slags, which they suggested might have been added intentionally 'to make the solidified slag more easily breakable' (Rothenberg \& Blanco-Freijeiro 1981: 68, 176 note 28). Tylecote (1987: 306-7) later suggested that the quartz was added at the end of the smelt to 'thicken' the slag, enabling it to be extracted easily from the furnace, lifting it off the melt. Craddock (2013: 245 note 13) argued the quartz was unreacted and that it was therefore added at the end of the process to 'quickly cool the slag making it much stiffer'. With specific reference to the presence of quartz in CA-EBA slags from the Trentino, D'Amico et al. (1998: 34) maintained that, since it was thermically altered, quartz was added as a silica flux to aid the smelting process, and this idea has been influential for the interpretation of the slags from the Trentino. Hauptmann et al. (1993, 2003: 205) 
and Hauptmann (2000: 108-109; 2020: 240-243), however, explained unmelted remains of host rock and quartz inclusions as restites, i.e. unmelted parts of a given charge.

\section{The 'Chalcolithic copper smelting model'}

It has been observed that early smelting was different to fully developed Bronze Age technologies (Hauptman 2000: 102). It is argued that all of the very earliest smelting processes were small scale and utilised very rich ores, typically oxide ore or mixed oxide-sulphide ore. No flux was added to the smelt, and the process was likely self-fluxing. The smelting produced small, nut-sized slags that were not fully liquefied and therefore non-optimised (from a modern viewpoint). As a result of the poor mastery of the smelting process, the slags show a poor level of reduction and separation and were thus wasteful, which meant that the slag often required manual beneficiation to separate out the prills of metallic copper (Hauptmann 2000: 101-116; Hauptmann et al. 2003; Bourgarit 2007).

\section{Previous analyses of CA/EBA slags from Trentino}

Storti (1991) published bulk quantitative analyses of four slags from La Vela di Valbusa. He hypothesised the use of chalcopyrite ore and suggested that three of the slags were matte smelting slags (his n.1, found to the west of the burial, and n.s 2 and 3, found to the north of the burial), while he suggested that a more glassy slag (n.4), found to the north of the burial, was produced while smelting matte to metallic copper (matte conversion), on the grounds of its higher composition of Fe-oxides and ZnO (Storti 1991: 351-3, tab1). He further argued that the area of fire-hardened clay was a roasting bed, noting that similar structures had been found at Tof de la Val, at Acquaviva di Besenello and at Montesei di Serso (Storti 1991: 354).

D'Amico et al. (1998) studied 12 slags from Riparo Gaban and ten from Acquaviva. They found phyllites and other quartz-bearing metamorphic rocks in the slags, and presence of relicts of chalcopyrite (D'Amico et al. 1998: 34). SEM-EDAX analysis of the glassy matrix reflected the composition of the phyllites $\left(\mathrm{SiO}_{2}, \mathrm{Al}_{2} \mathrm{O}_{3}, \mathrm{~K}_{2} \mathrm{O}\right)$, with the addition of $\mathrm{Fe}$ and $\mathrm{Zn}$, which presumably originated in the ore, and $\mathrm{CaO}$, which they suggested indicated the addition of a limestone flux. They found that the slags from Acquaviva were more homogeneous. Noting that $\mathrm{Zn}$ minerals were present, they argued that the chalcopyrite ore body was metamorphic in origin, that quartz was added as a flux and that differences in composition suggested different ore bodies which were exploited by the two sites. They concluded that the ore was most probably mined at Calceranica, a metamorphic deposit with pyrites, chalcopyrite and zinc blende, which is co-genetic with phyllites rich in quartz nodules (D'Amico et al. 1998: 37); this important deposit is situated to the east of Riparo Gaban and Acquaviva in the Valsugana. The same minerals are also present at Vetriolo (Levico Terme), close to Calceranica. Finally, they argued for a single smelt, made possible by the addition of a quartz flux.

Cattoi et al. (2000) present three CA-EBA slags, two from Tof de la Val and one from Romagnano Loch, along with slags from later Bronze Age sites in the Trentino. They argued that the abundant quartz in the slags was typical of the phyllites of the south Alpine basement (Cattoi et al. 2000: 129), so that the ore was metamorphic in nature; the high $\mathrm{K}_{2} \mathrm{O}$ and $\mathrm{Al}_{2} \mathrm{O}_{3}$ suggested micaceous-chloritic phyllites. This paper too argues that the quartz was added to the smelt as a flux and that Calceranica was the most likely provenance of the chalcopyrite ore. They further suggest that the $\mathrm{CaO}$ content is greater than is to be expected $(4.41 \%$ in the Romagnano Loch slag, $2.33 \%$ and $3.26 \%$ in those from Tof de la Val), indicating the addition of small amounts of carbonatic flux.

In a later article in English, Cattoi et al. (2001) summarise the results of D'Amico et al. (1998) and Cattoi et al. (2000). They confirm the presence of phyllites and quartz-bearing metamorphic rocks and again argue that the abundance of quartz in the slag is a result of its addition as a flux and that calcite too must have been added as its abundance is 'not compatible with phyllitic chemical compositions' (Cattoi et al. 2001: 152).

Anguilano et al. (2002) describe thin sections of CA, EBA and later Bronze Age slags, noting the stages through which the chalcopyrite is reduced to metallic copper. Following Donaldson (1976), they suggest on the basis of the fayalitic olivine crystals identified that the coarse slags cooled at a rate of $1-50{ }^{\circ} \mathrm{C}$ per hour, which they claim 'would indicate a total of at least $20 \mathrm{~h}$ for the cooling of the coarse slags to room temperature' (Anguilano et al. 2002: 636). They confirm the hypothesis of a two-stage smelting, hypothesising that there may also have been preliminary roasting, but note that according to D'Amico et al. (1998), where no platy slag is present (for example, at CA-EBA sites), the process was one-step.

As part of her major study of RBA and FBA slags, Beate Metten (2003: 8, 74-7, Figs. 34-6, pictures 33-6, tables 28-32) studied coarse slags from Acquaviva, La Vela di Valbusa, Montesei di Serso, Romagnano Loch, Romagnano Tof de la Val and Romagnano Angeli, plus a platy slag from Romagnano Angeli. She noted that chalcopyrite and pyrite were smelted but suggested that the presence of magnetite agglomerations associated with copper prills might indicate that at least part of the charge was secondary ores.

Colpani et al. (2009) present analyses of slags from the Alto Adige/Südtirol province, 25 from Millan/Milland and 12 from Gudon/Gufidaun-propr. Plank. Both sites have 
both coarse and dense slags; the latter are more homogeneous, have fewer vesicles and less gangue material, but more copper droplets, and so are argued to represent a more advanced stage in the smelting process. Platy slags (often called Plattenschlacken in the literature) are reported only at Gudon and show low viscosity. The ore is identified as chalcopyrite with accessory sphalerite and galena, and it is argued on the basis of the fayalitic olivine crystals that the coarse slags cooled at a slower rate $\left(<100{ }^{\circ} \mathrm{C}\right.$ per hour $)$ than the dense slags (up to $500{ }^{\circ} \mathrm{C}$ per hour).

Artioli et al. (2009) summarise investigations of early slags, including the sites of Gudon, Millan, Acquaviva, Riparo Gaban, La Vela di Valbusa, Croz del Cius, Romagnano Loch and Montesei di Serso in our study area. While they found only coarse slags at Millan, Acquaviva, Riparo Gaban and La Vela, they report platy slags from Gudon, Montesei di Serso and Romagnano Loch, with wüstite present in platy slags from Montesei di Serso and Romagnano Loch. Some of the coarse slags showed 'a more advanced degree of transformation' (Artioli et al. 2009: 17), with 30-40 wt\% magnetite and no quartz inclusions. Dense coarse slags with high magnetite content were found at Gudon, Millan and Romagnano Loch. A fragment of chalcocite-rich matte was identified from Montesei di Serso (Artioli et al. 2009: 17). They were unsure whether the quartz was added as a flux or present as gangue material, and whether smelting was one-step or two. They suggested that the chalcopyrite ores were associated with sphalerite (Millan) and tennantite-tetrahedrite (Montesei di Serso and Romagnano Loch). They commented that most of the CA "coarse slags are unbroken and slowly cooled in the furnace indicates that the molten matte was already efficiently removed from the slags during the high-temperature operations, without the need of extracting matte prills from the cold slags by breaking them' (Artioli et al. 2009: 18).

Angelini et al. (2013) provide a brief review, noting that the CA and EBA slags they analysed fit with the 'Chalcolithic copper smelting model' (Hauptmann 2000; Hauptmann et al. 2003; Bourgarit 2007), in as much as they are mineralogically heterogeneous, contain large quantities of non-reacted phases and do not have a homogeneous liquidus phase, showing no evidence for the addition of fluxes.

Artioli et al. (2015) present $\mathrm{Pb}$-isotope analyses for CA slags from the study area, arguing that the Trentino smelting sites of Acquaviva, Riparo Gaban, La Vela di Valbusa and Romagnano Loch in the Adige/Etsch Valley show 'affinity to the ores of the Pre-Variscan massive deposits related to the Hercynian basement' and the ores are therefore likely to have been mined at Calceranica (Artioli et al. 2015: 81; thereby confirming D'Amico et al.'s (1998) considerations on the mineralogy of the slag inclusions). Although Montesei di Serso is close to Calceranica, 'Post-Variscan sulphidic ores related to Permian and Triassic volcanics' were smelted at this site and the Alto Adige/Südtirol sites (Millan, Gudon, Bressanone/Brixen Circonvallazione Ovest) (Artioli et al. 2015: 81). Summarising previous work, they state that 'All the investigated smelting slags from Trentino (Romagnano Loc, La Vela, Gaban, Acquaviva di Besenello, Montesei di Serso) and Alto Adige/Sud Tyrol (Millan, Gudon, Bressanone Circonvallazione Ovest) have been recently characterized ... and demonstrated to be the product of copper smelting activities of chalcopyrite-based mineral charges, with an immature technological extraction process referred as the "Chalcolithic" smelting process' (Artioli et al. 2015: 78).

\section{The Himalayan smelting method: an ethnographic model}

Blanford (1861) describes in detail a traditional method of smelting he observed in Sikkim, which is similar to the process observed by Nils Anfinset (2001: 47-61, figs 10-20, tabs 5-7) in Okharbot, western Nepal. The two accounts appear to describe the same process, but the two perceived and interpreted what they observed differently. Some details that were noted by one are ignored by the other. For example, the multiple cycles of ore charging and the continual removal of slag cakes during the first smelt, clearly described by Blanford (1861: 390), are not mentioned explicitly by Anfinset but can be inferred from the information supplied in the tables and by the mention that during smelting the bellowers take short breaks to take out slag (Anfinset 2001: 51). According to the descriptions, the copper ore is first enriched by washing. The bottom of the furnace is filled with a bed of crushed charcoal in order to stop the copper sinking to the bottom of the furnace. Air is delivered from above through long tuyères reaching into the centre of the furnace. Blanford (1861: 390) describes the first smelt as a fusion process where charcoal is used to melt the "crude metal' or copper matte out of the ore and the waste accumulates as slag cakes, which are lifted from the furnace with pincers. The cyclical process of charging and slag lifting was repeated continuously until enough matte was collected in the bottom of the furnace. Anfinset adds that matte conversion slag from previous smelts is continuously added to the first smelt to accelerate the melting and instead of using pincers, simple wooden sticks are used to stir and lift the slag from the furnace. After around $45 \mathrm{~min}$, 'the smith takes a wooden stick and stirs roughly in the furnace to separate the slag and the molten metal even more, while the bellows are continually worked'; after a few minutes, the charcoal is then removed, and the slag is allowed to cool (Anfinset 2001: 52). Once the slag has hardened, it can be lifted out of the furnace using wooden sticks, leaving the accumulated copper matte in the bottom of the furnace to cool. The matte is then crushed and ground and mixed with cow dung to form small balls, which are then roasted using tree bark as fuel. 
The matte and cow dung balls are then placed in the furnace for a second, matte conversion smelt. The furnace is stirred occasionally by the smith with a wooden stick in order to speed 'up the separation of the slag from the molten metal' (Anfinset 2001: 53-54). The slag is then removed at regular intervals using two wooden sticks, until only copper is left in the furnace. Slag from the second smelt 'is reused in the next first smelt because it is said to speed up the smelting process' (Anfinset 2001: 55).

Since 2001, researchers have begun to apply these ethnographic examples to the study of Late Bronze Age Alpine smelting technology, particularly through experimental archaeology (Goldenberg et al 2011; Hanning 2012; Della Casa et al. 2016; Reitmaier-Naef 2019; Rose et al. 2021), but this has yet to be applied to evidence from the earliest phase of copper production in the Chalcolithic/Early Bronze Age.

\section{Research questions}

In this paper, on the basis of our observations and analyses of slag cakes from La Vela di Valbusa and the Riparo di Monte Terlago, we seek to reconstruct the smelting process used to produce copper in the third millennium cal BC Trentino, north-eastern Italy.

\section{Methods}

Seven slag pieces were investigated to determine their mineralogical and chemical composition and to describe the petrographic texture of the slags (Fig. 3; Table 2). As noted above (cf. Table 1), a number of CA slags from the Trentino have previously been analysed by other workers, including slags from La Vela di Valbusa. On the other hand, slags from the Riparo di Monte Terlago have not

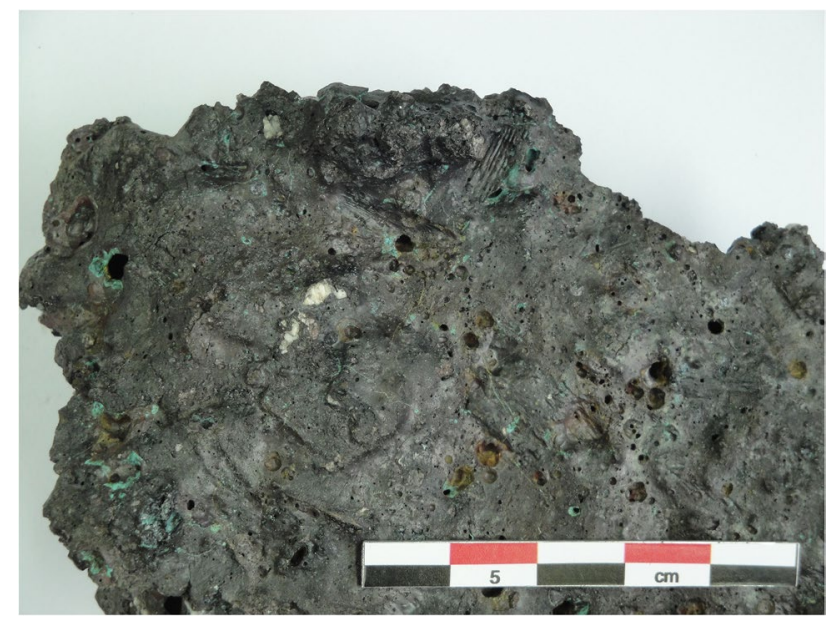

Fig. 3 Detail of slag VB5, showing charcoal (note the cell structure of the wood) and whiteish quartz inclusions been previously studied. We therefore chose to investigate in detail five slags from the Riparo di Monte Terlago and two slags from La Vela di Valbusa. It should be stressed that we looked at complete profiles of the slags, which has not been done before for slags of this period from the area, rather than thin sections from a larger number of slags. The wide cross-section of three slag cakes required multiple mounted thin sections, each of which was separately analysed (MT13: 3 thin sections; VB2: 4 thin sections; VB 10: 4 thin sections-see Fig. 4). All the slags are visually and morphologically similar, and all appear to contain the same constituents (Fig. 3). They belong to a relatively standardised technological process. The overall sample number therefore reflects the heterogeneity of the assemblage - the more heterogeneous it is, the more samples need to be taken. The slags were first sawn and slices were mounted as polished thin sections, and fragments were cut and milled for X-ray diffraction (XRD) and inductively coupled-plasma mass spectrometry (ICP-MS) at the laboratory of the Deutsches Bergbau-Museum Bochum. The profiles of three slag cakes (MT13, VB2 and VB10) were mounted in three or four thin sections to better assess the overall heterogeneity of the material (Fig. 4).

The thin sections were prepared by grinding to a thickness of $30 \mu \mathrm{m}$ and polishing the surface with abrasives and lead. This allows the slides to be viewed with transmitted and reflected light microscopy and scanning electron microscopy (SEM). A Zeiss Axiophot optical microscope was used as well as a Zeiss Gemini SEM with energy dispersive X-ray spectroscopy (EDS) capabilities (Thermo UltraDry Silicon Drift X-ray Detector). The slides were not coated with carbon and were thus analysed under low vacuum conditions (30-50 Pascal). An energy of $20 \mathrm{kV}$ and a working distance of $13.3-16.4 \mathrm{~mm}$ were used. The EDS NSS software (Noran System Seven) uses a fitted standard calibration and can be viewed as semi-quantitative.

Approximately $20 \mathrm{~g}$ from each slag sample were crushed using steel implements and milled in portions with an agate ball mill to grain sizes under $30 \mu \mathrm{m}$. The XRD was performed on milled samples using a PANalytical X'Pert instrument (PRO MPD) with X'Celerator detector and HighScore Plus software for analytical interpretation. The analysis requires about $100 \mathrm{mg}$ of homogenised powdered sample $(<0.063 \mathrm{~mm}$ fraction size $)$, and the samples were analysed with ADS (automatic divergence slit) $\mathrm{Cu}-\mathrm{K} \alpha$-radiation of $1.54178 \AA$ at $45 \mathrm{kV}(40 \mathrm{~mA})$ with angle array set to $5-70^{\circ} 2$-theta at a rate of $0.017^{\circ} / 10 \mathrm{~s}$.

The digestion of the slag for quantitative ICP-MS was carried out with a $\mu$ PREP-A microwave using concentrated acids. The sample size was $100 \mathrm{mg}$ of homogenised pulverised material. The sample material was digested in PTFE pressure vessels with a mixture of concentrated acids $(6 \mathrm{ml}$ $\mathrm{HCl}: 1.75 \mathrm{ml} \mathrm{HF}: 4.8 \mathrm{ml} \mathrm{HNO}_{3}$ ) for $40 \mathrm{~min}$ at $250{ }^{\circ} \mathrm{C}$. In a second step, $10 \mathrm{ml}$ of boric acid $(50 \mathrm{~g} / \mathrm{l})$ was added, and the samples were then heated to $200{ }^{\circ} \mathrm{C}$ for $20 \mathrm{~min}$ to avoid 
Table 2 List of slag investigated in this study. Seven slag samples were selected for sampling (*)

\begin{tabular}{|c|c|c|c|c|c|}
\hline \multicolumn{6}{|c|}{ Riparo di Monte Terlago, Terlago TN, Italy } \\
\hline Arch. ID & Lab ID & Material & Weight $(\mathrm{g})$ & $1 \times w \times$ th $(\mathrm{mm})$ & \\
\hline MT2 & $4364 / 16$ & Slag & 20 & $43 \times 33 \times 18$ & \\
\hline MT3 & $4365 / 16$ & Slag & 41 & $44 \times 38 \times 16$ & \\
\hline MT4 & $4366 / 16$ & Slag & 48 & $58 \times 38 \times 21$ & \\
\hline MT5 & $4367 / 16$ & Slag & 123 & $84 \times 69 \times 26$ & \\
\hline MT6 & $4368 / 16$ & Slag & 27 & $49 \times 35 \times 28$ & \\
\hline MT7* & $4369 / 16$ & Slag & 60 & $49 \times 43 \times 22$ & \\
\hline MT8* & $4370 / 16$ & Slag & 16 & $36 \times 29 \times 12$ & \\
\hline MT9 & $4371 / 16$ & Slag & 14 & $31 \times 27 \times 10$ & \\
\hline MT10* & $4372 / 16$ & Slag & 22 & $50 \times 36 \times 21$ & \\
\hline MT11* & $4373 / 16$ & Slag & 15 & $37 \times 24 \times 15$ & \\
\hline MT12 & $4374 / 16$ & Slag & 13 & $32 \times 26 \times 24$ & \\
\hline MT13* & $4375 / 16$ & Slag & 158 & $82 \times 59 \times 27$ & \\
\hline \multicolumn{6}{|c|}{ La Vela di Valbusa, Trento TN, Italy } \\
\hline Arch. ID & Lab ID & Material & Weight (g) & $1 \times w \times$ th $(\mathrm{mm})$ & Comments \\
\hline VB1 & $4376 / 16$ & Slag & 436 & $140 \times 117 \times 43$ & Mostly complete; impression from pole and tong marks on upper surface \\
\hline $\mathrm{VB} 2 *$ & $4377 / 16$ & Slag & 418 & $146 \times 115 \times 25$ & Mostly complete; impression from pole and tong marks on upper surface \\
\hline VB3 & $4378 / 16$ & Slag & 298 & $123 \times 77 \times 31$ & \\
\hline VB4 & $4379 / 16$ & Slag & 16 & $50 \times 25 \times 16$ & \\
\hline VB5 & $4380 / 16$ & Slag & 359 & $117 \times 75 \times 37$ & Impression from wooden pole and tong marks on underside \\
\hline VB6 & $4381 / 16$ & Slag & 307 & $122 \times 84 \times 26$ & Tong marks on upper surface \\
\hline VB7 & $4382 / 16$ & Slag & 197 & $95 \times 72 \times 30$ & \\
\hline VB8 & $4383 / 16$ & Slag & 262 & $93 \times 85 \times 29$ & Tong marks on upper surface \\
\hline VB9 & $4384 / 16$ & Slag & 219 & $100 \times 71 \times 29$ & \\
\hline VB10* & $4385 / 16$ & Slag & 280 & $129 \times 92 \times 26$ & Mostly complete, tong marks on upper surface \\
\hline VB11 & $4386 / 16$ & Slag & 250 & $122 \times 69 \times 31$ & \\
\hline
\end{tabular}

$M T$ Monte Terlago, VB La Vela di Valbusa, $l$ length, $w$ width, and $t h$ thickness

the precipitation of calcium fluoride and aluminium fluoride. Finally, digestions were diluted with ultra-pure water up to $100 \mathrm{ml}$. The ICP-MS analyses were performed using a Thermo Scientific ELEMENT XR with ISDS software. The analyses were carried out with a FAST SC-system, ST 5532 PFA $\mu$-FLOW nebuliser, Peltier-cooled PFA spray chamber and $1.8 \mathrm{~mm}$ sapphire injector in triple detector mode at all three different mass resolutions $(\mathrm{m} / \Delta \mathrm{m})$ depending on the elements of interest. Twenty-four elements were measured (Na, Mg, Al, Si, P, S, K, Ca, Ti, Cr, Mn, Fe, Co, Ni, Cu, Zn, $\mathrm{As}, \mathrm{Ag}, \mathrm{Sn}, \mathrm{Sb}, \mathrm{Ba}, \mathrm{Pb}, \mathrm{Bi}$ and $\mathrm{U})$.

\section{Results}

\section{General observations}

Eleven slag fragments from La Vela di Valbusa were available for study (VB1-11). The whole slag cakes seem to have had an original diameter of $12-14 \mathrm{~cm}$ and weighed up to
$436 \mathrm{~g}$. They had relatively flat faces, with bubbles and protuberances. Some showed signs of having been broken in antiquity (e.g. VB4). Indentations were noted on a number of slags; for example slag VB1, which is virtually whole, has a v-shaped indentation on one face (Fig. 8), while the other face has a depression corresponding to the indentation, with protuberances around it. Most of the slag fragments had inclusions visible to the naked eye, such as quartz and chalcopyrite ore. Figure 3 shows a detail of slag VB5, with quartz and charcoal inclusions clearly visible. A large area of matte was visible on the lower face of fragment VB6.

The thirteen slag fragments from the Riparo di Monte Terlago included in the study are much more fragmentary than those from La Vela di Valbusa and generally had much fewer and smaller inclusions but are more likely to have visible charcoal impressions. Inclusions visible to the naked eye include light-coloured fragments of rock and quartz.

Sections of three slag cakes can be seen in Fig. 4; they show a coarse breccia texture with numerous bubbles and 
Fig. 4 Sections of three slag cakes from top to bottom: MT13, VB2 and VB10. All slags show a pronounced heterogeneous breccia-like texture with large and small, partially angular inclusions of rock fragments and numerous bubbles imbedded in a black slag
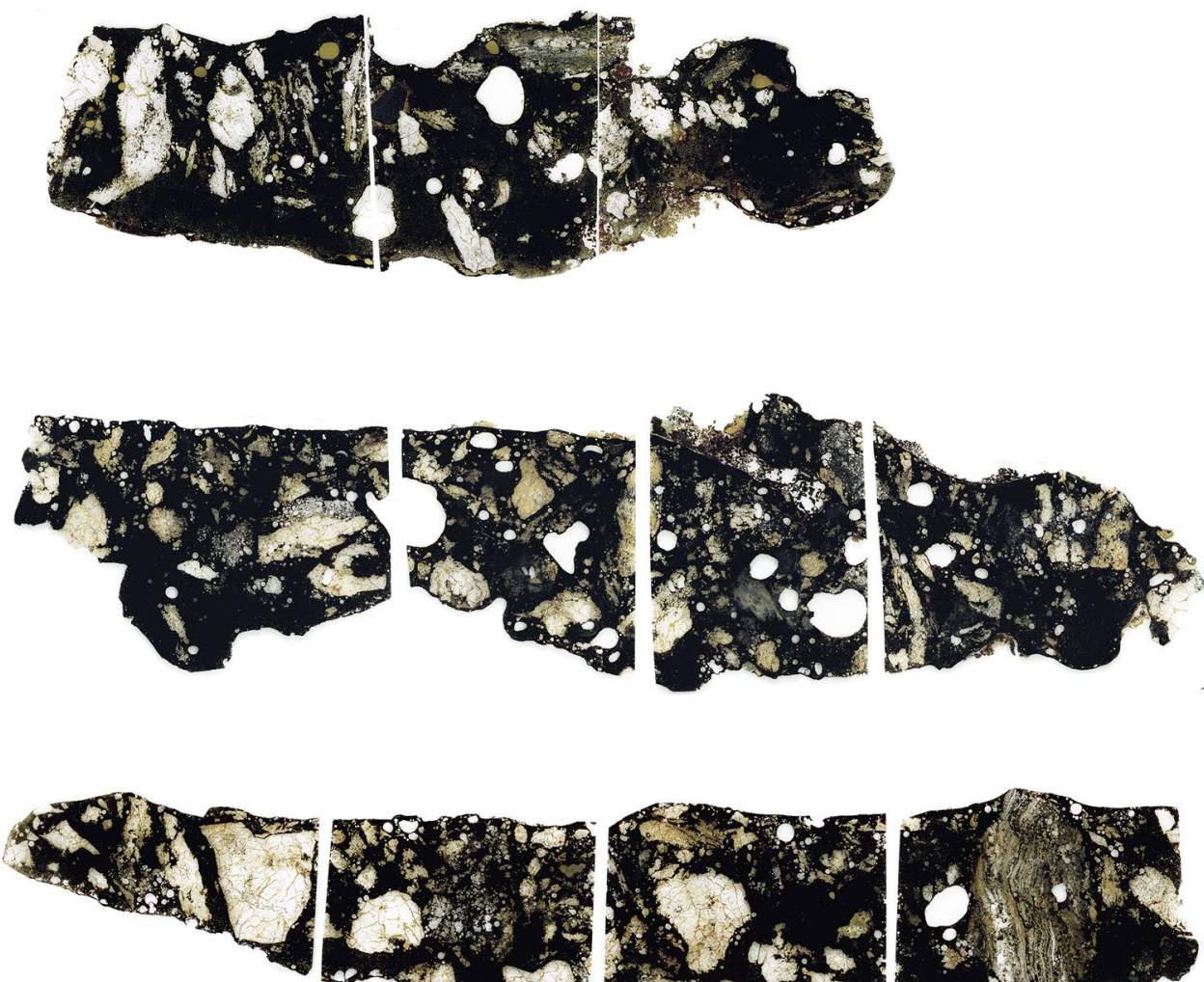

$2.5 \mathrm{~cm}$
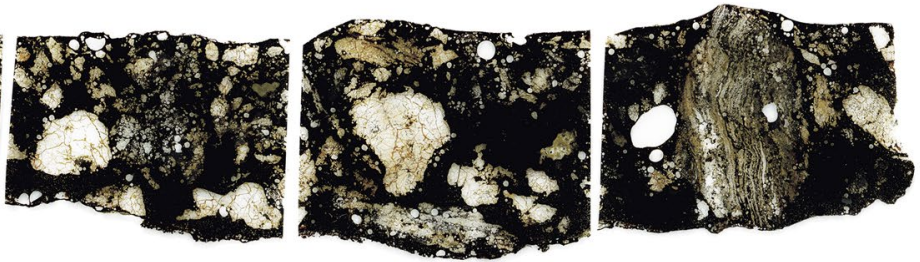

laminated and fractured angular rock fragments imbedded in a black slag.

The XRD results and the bulk slag compositions determined by ICP-MS can be found in Tables 3 and 4 .

\section{Microscopy: inclusions and phases}

\section{Rock inclusions}

The slag cakes contain abundant rock inclusions that are commonly associated with chalcopyrite and pyrrhotite (Fig. 5a). The large rock inclusions were heavily altered during smelting. They often have foliated texture consistent with metamorphic rock, resembling schist, and consist primarily of quartz, relics of phyllosilicates and ore minerals. Cristobalite, a high-temperature form of $\mathrm{SiO}_{2}$, could be identified both by optical microscopy (Fig. 6a) and XRD of two quartz inclusions (MT13, VB2), and between the bands of quartz, the phyllosilicates are almost entirely vitrified exhibiting a glassy, bubbly structure. In very few cases can feldspars be observed, but one example is in MT8 where microcline (K-feldspar) is present in gneiss together with quartz and mica. In addition to foliated rock inclusions, fine-grained rock inclusions mostly consisting of ferromagnesian aluminosilicates with compositions similar to iron-rich chlorite were found in all slag samples. These rock inclusions are relatively homogeneous agglomerations of small $(<100 \mu \mathrm{m})$ flake-like crystals and often pyrrhotite and chalcopyrite fill the porosity. Chlorites can be formed by hydrothermal alteration of igneous rocks and during metamorphism, i.e. chloritic schist (Deer et al. 1962: 131), and some iron-rich chlorite minerals can be associated with sulphide ore minerals (Doelter 1921: 324-5), as appears to be the present case.
Table 3 X-ray diffraction results of the slag samples and two rock inclusions extracted from the slag $(*)$

\begin{tabular}{llllllllll}
\hline & MT7 & MT8 & MT10 & MT11 & MT13 & VB2 & VB10 & MT13* & VB2* \\
\hline Quartz & $\mathrm{x}$ & $\mathrm{x}$ & $\mathrm{x}$ & $\mathrm{x}$ & $\mathrm{x}$ & $\mathrm{x}$ & $\mathrm{x}$ & $\mathrm{x}$ & $\mathrm{x}$ \\
Tridymite & & & $\mathrm{x}$ & $\mathrm{x}$ & $\mathrm{x}$ & $\mathrm{x}$ & $\mathrm{x}$ & & \\
Cristobalite & & $\mathrm{x}$ & & & $\mathrm{x}$ & $\mathrm{x}$ & & $\mathrm{x}$ & $\mathrm{x}$ \\
Fayalite (magnesian) & $\mathrm{x}$ & $\mathrm{x}$ & $\mathrm{x}$ & $\mathrm{x}$ & $\mathrm{x}$ & $\mathrm{x}$ & $\mathrm{x}$ & & \\
Magnetite & $\mathrm{x}$ & & $\mathrm{x}$ & & $\mathrm{x}$ & & & & \\
Hercynite & & $\mathrm{x}$ & $\mathrm{x}$ & $\mathrm{x}$ & $\mathrm{x}$ & $\mathrm{x}$ & $\mathrm{x}$ & & \\
\hline
\end{tabular}


Table 4 ICP-MS bulk slag compositions. Values of main and minor components are given in weight percent (\%) and trace elements in parts per million (ppm)

\begin{tabular}{|c|c|c|c|c|c|c|c|}
\hline & $\begin{array}{l}\text { MT7 } \\
\%\end{array}$ & $\begin{array}{l}\text { MT8 } \\
\%\end{array}$ & $\begin{array}{l}\text { MT10 } \\
\%\end{array}$ & $\begin{array}{l}\text { MT11 } \\
\%\end{array}$ & $\begin{array}{l}\text { MT13 } \\
\%\end{array}$ & $\begin{array}{l}\text { VB2 } \\
\%\end{array}$ & $\begin{array}{l}\text { VB10 } \\
\%\end{array}$ \\
\hline $\mathrm{SiO}_{2}$ & 46.5 & 43.4 & 47.7 & 51.7 & 43.8 & 45.9 & 51.7 \\
\hline $\mathrm{TiO}_{2}$ & 0.22 & 0.29 & 0.22 & 0.29 & 0.21 & 0.35 & 0.27 \\
\hline $\mathrm{Al}_{2} \mathrm{O}_{3}$ & 6.29 & 7.94 & 7.45 & 8.41 & 6.97 & 9.06 & 8.13 \\
\hline $\mathrm{FeO}$ & 28.9 & 32.2 & 29.8 & 26.4 & 30.6 & 27.1 & 26.8 \\
\hline $\mathrm{MnO}$ & 0.17 & 0.21 & 0.21 & 0.24 & 0.20 & 0.21 & 0.15 \\
\hline $\mathrm{MgO}$ & 3.04 & 3.94 & 3.94 & 4.31 & 3.61 & 4.35 & 3.88 \\
\hline $\mathrm{CaO}$ & 4.84 & 7.12 & 6.32 & 2.62 & 3.22 & 2.49 & 1.52 \\
\hline $\mathrm{BaO}$ & 0.01 & 0.02 & 0.01 & 0.01 & 0.005 & 0.01 & 0.01 \\
\hline $\mathrm{ZnO}$ & 1.66 & 1.27 & 2.35 & 1.19 & 1.79 & 0.79 & 0.42 \\
\hline $\mathrm{K}_{2} \mathrm{O}$ & 0.87 & 0.69 & 0.60 & 0.46 & 0.75 & 0.85 & 0.54 \\
\hline $\mathrm{Na}_{2} \mathrm{O}$ & 0.05 & 0.08 & 0.06 & 0.06 & 0.05 & 0.06 & 0.19 \\
\hline $\mathrm{P}_{2} \mathrm{O}_{5}$ & 0.41 & 0.30 & 0.37 & 0.16 & 0.18 & 0.16 & 0.12 \\
\hline $\mathrm{S}$ & 1.16 & 1.08 & 0.93 & 0.59 & 1.30 & 1.29 & 1.12 \\
\hline $\mathrm{Cu}$ & 1.41 & 0.87 & 0.46 & 0.57 & 1.92 & 1.81 & 1.37 \\
\hline \multirow[t]{2}{*}{ Total } & 95.5 & 99.4 & 100.4 & 97.0 & 94.6 & 94.3 & 96.3 \\
\hline & ppm & ppm & ppm & ppm & ppm & ppm & ppm \\
\hline $\mathrm{Pb}$ & 1300 & 690 & 1100 & 1200 & 2300 & 840 & 300 \\
\hline $\mathrm{Ag}$ & 25 & 5 & 6 & 7 & 20 & 20 & 9 \\
\hline As & 45 & 95 & 120 & 40 & 30 & 55 & 35 \\
\hline $\mathrm{Sb}$ & 1860 & 250 & 2200 & 610 & 1400 & 110 & 180 \\
\hline $\mathrm{Bi}$ & 15 & 4 & 20 & 6 & 30 & 8 & 15 \\
\hline Co & 170 & 150 & 170 & 90 & 210 & 90 & 110 \\
\hline $\mathrm{Ni}$ & $<5$ & $<5$ & 15 & $<5$ & $<5$ & $<5$ & $<5$ \\
\hline $\mathrm{Cr}$ & 15 & 20 & 40 & 20 & 11 & 30 & 15 \\
\hline Sn & 30 & 35 & 25 & 15 & 35 & 20 & 40 \\
\hline U & 1.7 & 1.8 & 1.8 & 1.7 & 1.9 & 2.0 & 2.8 \\
\hline
\end{tabular}

\section{Olivine}

One of the most commonly encountered phases in the slag is olivine. The olivines in the slag are in the forsterite $(\mathrm{Mg}-$ rich, Fo)-fayalite (Fe-rich, Fa) system and are exclusively on the fayalite side of the spectrum. The olivine crystals in slag from both smelting sites often exhibit zonation with a core richer in magnesium oxide a phenomenon that has been described in later Bronze Age slags from Trentino (Addis et al. 2017: 990). The high magnesium oxide contents ( $\mathrm{Fo} \approx 28 \%$ ) were found in some cores, but most of the 28 olivine cores analysed were much richer in iron (Fo $\approx 18 \%$, or $57 \mathrm{wt} \% \mathrm{FeO})$. Following the work of Bowen and Schairer (1935), within the pure system, the cores of the olivine richest in magnesium oxide would crystallise at a temperature around $1320{ }^{\circ} \mathrm{C}$ and finalise with the crystallisation of olivine richer in iron between 1220 and $1240{ }^{\circ} \mathrm{C}$. This means that a c. $80-100{ }^{\circ} \mathrm{C}$ temperature difference existed between the initial crystallisation and the termination of crystal growth. In reality, i.e. in our slags, the temperatures are lower due to the interaction of olivine crystallisation with other constituents in the charged material. The olivine crystals in the slag show diverse morphological crystallised features, but the most prominent forms are hoppers that range from euhedral crystals to hollow elongated structures with marked edge growth (Fig. 5b). It is clear that olivine did not achieve equilibrium with the surrounding liquid melt because of the presence of secondary olivine phases that quickly crystallised out of solution as the melt reached the olivine solidus temperature. The hoppers are normally under $100 \mu \mathrm{m}$ in much of the slag, but there is a perceptible tendency for the olivine hoppers at the bottoms of the slag cakes to be up to twice the size of those on the upper parts of the slag, reaching sizes up to $200 \mu \mathrm{m}$.

\section{Spinels and iron-rich regions}

Spinels of the hercynite-magnetite series are found in every slag, and both end members are present. Aluminium oxiderich spinels are distributed fairly homogeneously throughout the slag. Rims of hercynite can be found surrounding chlorite-like rock inclusions that were being attacked by the slag. The presence of this phase reflects the content of aluminium 

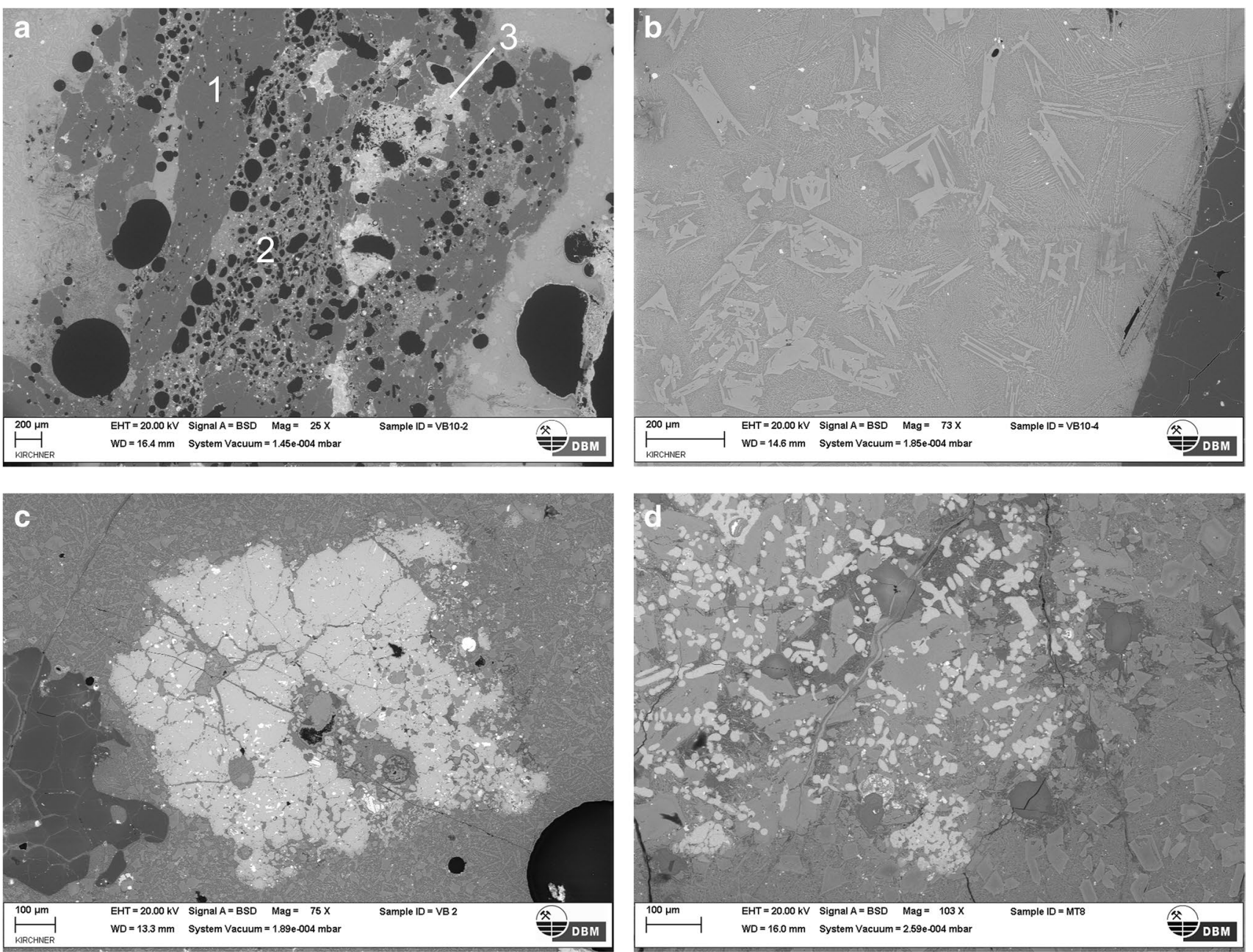

Fig. 5 Scanning electron microscope backscatter images. a Slag VB10, slide 2: fragment of ore and gangue minerals decomposing and vitrifying inside the slag. The gangue exhibits a laminated texture with quartz (1) and decomposed phyllosilicates (2). The metalliferous phases (3) primarily consist of chalcopyrite together with lesser amounts of bornite, magnetite and pyrrhotite. b Slag VB10, slide 4: fayalite crystals in glassy slag with small sulphide inclusions (white)

oxide in the melt. Iron oxide-rich spinels, though present in all slags, are much rarer and tend to be in the form of agglomerates or bands. The iron oxide-rich spinels are either remnants of iron oxide-bearing minerals from the charge or formed from the oxidation of the matte or the slag surface. Bands of magnetite formed by brief exposure to oxygen on the surface of the slag, particularly as oxidation rims of sulphides at the slag's surface: these bands, or oxidation rims, appear sometimes within the slag (Fig. 6b-c). These rims mark former upper surfaces of the slag, and their displacement within the slag is the result of movement possibly from stirring the slag with a wooden pole, a practice observed by Anfinset (2001: 52) aimed at facilitating the separation of the slag and molten metal.

present throughout. The right edge shows a quartz-rich inclusion. c Massive magnetite in slag VB2-3. The inclusion contains a range of copper-bearing inclusions from chalcopyrite to metallic copper with an emphasis on covellite. d Slag MT8, slide 2: iron-rich inclusion containing dendritic iron oxides, metallic copper prills and large tabular fayalite crystals in slag. The rounded morphology of the iron oxide dendrites points to wüstite or a wüstite/magnetite mixture

Iron-rich agglomerates tend to be between 0.5 and $3 \mathrm{~mm}$ in size with a few exceptional examples being larger. There is significant variation in the sizes, shapes and compositions of these inclusions. They are almost always associated with sulphides and/or metallic copper. Some are massive with small sulphide inclusions (Fig. 5c), and others are reminiscent of slag with dendritic wüstite/magnetite, fayalite and metallic copper (Fig. 5d). A number of this later type of inclusion exist and all contain metallic copper, which is found almost nowhere else in the slags. The fayalite morphology in these inclusions is discordant with the surrounding slag; in these inclusions, the fayalite crystals are typically larger and more fully developed than the surrounding slag. 


\section{Copper and iron sulphides}

Copper-iron and iron sulphides are present in all slag specimens. The slag fragments have all been subjected to weathering causing many of the sulphides to corrode or to be replaced with other minerals such as covellite, cuprite, hematite and iron-copper sulphate minerals. Sulphides can be divided into three categories: sulphides trapped in gangue, sulphides trapped in slag and the matte sulphide layer that adheres to the bottoms of the slag cakes. The sulphides in gangue rock are almost exclusively pyrrhotite and chalcopyrite, often with little visible decomposition to bornite and magnetite due to smelting (Fig. 6d). The sulphides in the melted regions of the slag are typically of spherical form, sometimes adjoined to bubbles, and show a much larger compositional variability in the $\mathrm{Cu}: \mathrm{Fe}$ ratio; however, chalcopyrite and pyrrhotite are nearly always dominant, with subsidiary bornite and magnetite (Fig. 6e). The intermittent matte layers on the bottom of the slag cakes are typically between $100 \mu \mathrm{m}$ and $1 \mathrm{~mm}$ thick and are heavily impacted by corrosion. Only small islands of sulphides remain (Fig. 6f); however, the magnetite tends to be stable and shows extensive exsolution and/or eutectic patterns with sulphides that are no longer present due to corrosion. The matte layer is almost always rimmed with a continuous $10-20 \mu \mathrm{m}$ thick magnetite crust where the hot matte would have been exposed to air. Given the range of compositions, the melting point of the sulphides is between c. 941 and $1100{ }^{\circ} \mathrm{C}$ (Schlegel and Schüller 1952).

\section{X-ray diffraction (XRD)}

The XRD analyses help to confirm the mineral and phase identifications and show broadly similar characteristics. All contain quartz and fayalitic olivine and most contain sizeable quantities of high temperature silica phases (tridymite and cristobalite) and aluminium oxide-rich spinels (hercynite). Magnetite is less frequently found in significant quantities, and as the microscopy shows, it tends to be found in small agglomerations or as oxidised crusts on the upper and lower surfaces of the slags. a

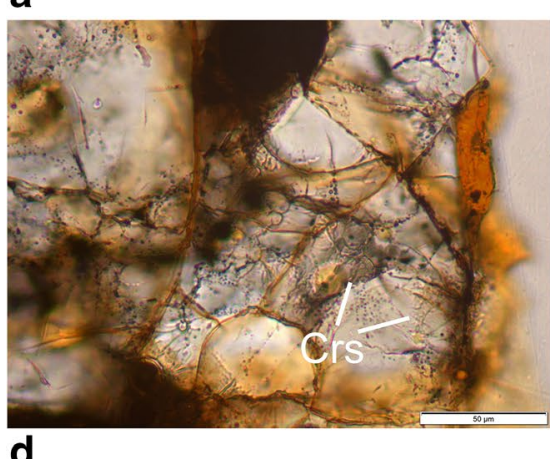

d

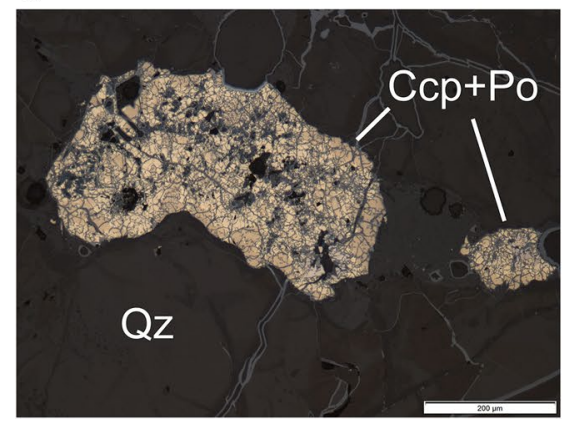

b

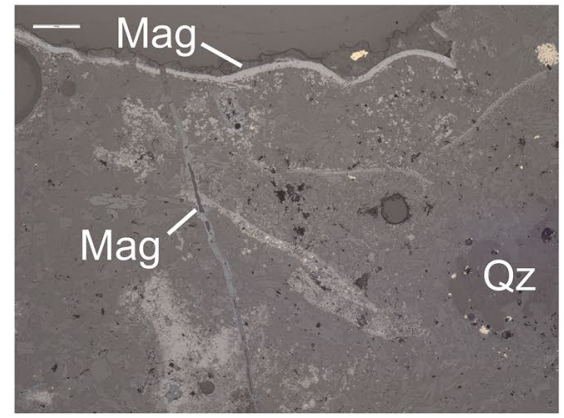

e

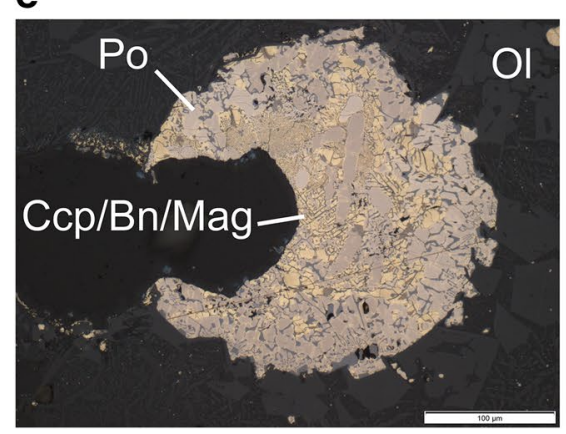

c

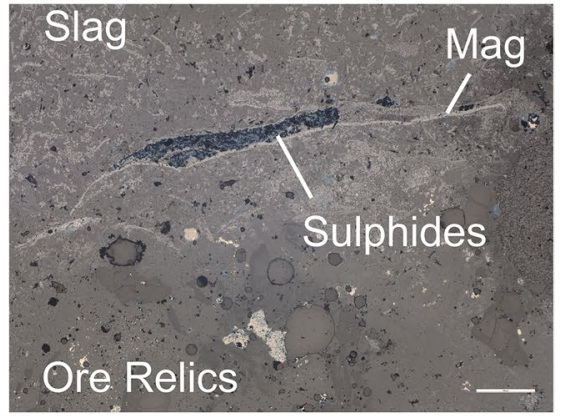

f

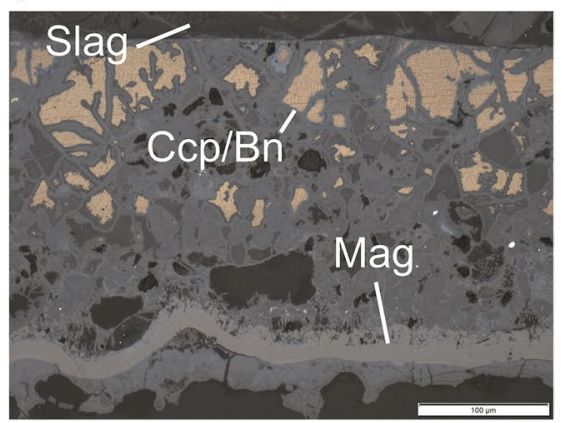

Fig. 6 Optical microscope images. a Quartz-rich inclusion in slag MT11 showing high temperature alteration and the formation of cristobalite (Crs). Note the so-called ballen texture (Flörke 1959). Transmitted light, scale bar $50 \mu \mathrm{m}$. b Magnetite rim on the upper surface of slag MT13 and remnants of magnetite rims within slag. Reflected light, scale bar $200 \mu \mathrm{m}$. c Magnetite rim within slag MT13 with trapped sulphide layer above. Reflected light, scale bar $500 \mu \mathrm{m}$. d Sulphide inclusion containing chalcopyrite (Ccp) and pyrrhotite (Po) in quartz-rich gangue (Qz) fragment in slag VB10-3 which are likely to reflect the type of ore used during smelting. Reflected light, scale bar $200 \mu \mathrm{m}$. e Melted sulphide inclusion in slag VB10-4 adhering to a bubble. The inclusion is dominated by chalcopyrite and pyrrhotite with lesser amounts of bornite (Bn) and magnetite (Mag). The surrounding slag is glassy with crystals of fayalite olivine $(\mathrm{Ol})$. Reflected light, scale bar $100 \mu \mathrm{m}$. f Matte layer on the base of slag VB10 approximately $0.25 \mathrm{~mm}$ thick. The layer represents a mixed sulphide/ oxide melt with relics of chalcopyrite with minimal bornite exsolution and magnetite eutectic and exsolution phases. The continuous magnetite rim is visible in the lower quarter of the image. Reflected light, scale bar $100 \mu \mathrm{m}$ 


\section{Inductively coupled plasma mass spectrometry (ICP-MS)}

The elemental analyses indicate that the slags contain ca. $0.5-2 \mathrm{wt} \%$ copper trapped in the slag. The copper content is directly correlated with sulphur $\left(r^{2}=0.8\right)$, and thus, this loss is almost exclusively as matte in the slag. The slag compositions are dominated by silica (43-53 wt $\%$ ), followed by iron oxide (ca. $30 \mathrm{wt} \%$ ) and aluminium oxide (6-9 wt\%) and calcium oxide (1.5-7 wt\%) and magnesium oxides (3-4 $\mathrm{wt} \%)$. The compounds titanium oxide and magnesium oxide are strongly correlated to aluminium oxide $\left(r^{2}=0.9\right)$ and must have entered the system together, probably as chloritic rock, but these are only weakly correlated with iron oxide, so there must be additional sources contributing iron oxide to the slag, either from other minerals accessory to the ore and/or an iron oxide-bearing flux. There are slight differences between the two sites in the relative quantities of some metalliferous impurities from accessory minerals in the ore. The slags from Riparo di Monte Terlago are often richer in zinc oxide and antimony than the slags from La Vela di Valbusa. These are not correlated with the copper content, so they represent heterogeneities in the mineral assemblage in the ore. The only trace element that is consistently associated with copper is silver $\left(r^{2}=0.7\right)$.

\section{Discussion}

\section{Comparison between the two sites}

Some differences were observed between the slags from the Riparo di Monte Terlago and La Vela di Valbusa. While some slag pieces at the Riparo di Monte Terlago are macroscopically indistinguishable, others are more gracile and thinner than the slags from La Vela di Valbusa. All the slags from the Riparo di Monte Terlago are fractured/fragmented, so none reflects a complete slag cake. MT13 is exactly like the La Vela di Valbusa slags in terms of shape, thickness, morphology and texture. MT4 and MT6 are also similar to the La Vela di Valbusa samples but are thinner. The rest of the Riparo di Monte Terlago samples are generally more compact and vitreous than the La Vela di Valbusa samples, and the rock inclusions are smaller. This difference, however, may simply be a bias of the sample selection. The edges of the large La Vela di Valbusa slags are sometimes of a similar thickness to the majority of the Riparo di Monte Terlago samples. It is not possible to undertake a proper comparison as the Riparo di Monte Terlago samples are fragments of slag cakes, whereas whole slag cakes were available from La Vela di Valbusa.

The slag fragments from the Riparo di Monte Terlago included in the study generally had much fewer and smaller inclusions than those from La Vela di Valbusa, but no significant differences were noted in the nature of the inclusions, and we suggest that the macroscopic differences observed reflect the heterogeneous nature of the slags rather than any difference in process between the two sites.

\section{Ore processing}

The ore must have been only coarsely crushed and beneficiated. In the slag cakes, there are centimetre-sized pieces of gangue rock inter-grown with ore minerals, of sizes that would have been selected by hand. Pulverisation and wet beneficiation steps, as described by Blanford (1861), were not performed. Anfinset (2001:48-9) also describes wet beneficiation preceded by hand sorting but comments that wet processing was not needed if the ore was of good quality. Both of these ethnographic accounts indicate that there was no roasting step prior to smelting, and the condition of the sulphides in ore fragments in the slag cakes we studied also shows no signs of it being first roasted.

\section{Cooling rates}

Following the work of Donaldson (1976), the types of olivine hoppers in the slag suggest cooling rates of $15-40{ }^{\circ} \mathrm{C}$ per hour (over the c. $80^{\circ} \mathrm{C}$ span of the initial crystallisation and the cessation of crystal growth between the olivine liquidus and solidus temperatures). However, the cooling rate described by Donaldson was based on forsterite-rich olivine and appears not be representative of the iron-rich systems found in archaeological slags (Ettler et al. 2009). Ettler et al. (2009) argue that, based on the work of Faure et al. (2003), the olivine morphology progression of fayalite occurs more quickly, with hopper-type crystals forming at cooling rates in the low hundreds of degrees per hour and chains at high hundreds of degrees per hour. The wooden (?) implement impressions and the fact that matte adhering to the underside of the slag formed magnetite crusts upon exposure to air indicate that the slag cakes were lifted while hot and were likely semi-solid. It is not unreasonable to assume that the slag solidified over the course of $10 \mathrm{~min}$ in the furnace before lifting. The olivine crystals do not tell us anything about the rate of cooling below their crystallisation temperature (contra Anguilano et al. 2002: 636).

\section{Flux or no flux}

The metamorphic rock inclusions in the slag are consistent with the other prehistoric slag known from Trentino-Alto Adige/Südtirol and described in the literature (full references in Table 1) and may have an origin in the pre-Variscan 
basement (D'Amico et al. 1998; Artioli et al. 2015). If calcium carbonates or iron carbonates were associated with the ore, we would expect to find relicts in the ore-bearing rock inclusions, either in the form of calcium oxide or iron oxide-rich melts or as iron oxide concentrations within the rock fragments, but these were not observed. The iron-rich chlorite minerals of the quartz-phyllite-dominated rocks appear to form the bulk of the slag, and one could argue that a mixture of gangue minerals was desired; however, they are still too iron-poor to produce a liquid slag at the temperatures used, but it is unlikely that a full liquefaction of slag was the main goal of the process. The slag phases show that they were capable of reaching the temperatures needed to produce a fully liquid slag had they crushed the rock into smaller pieces and slightly raised the iron content.

The calcium oxide contents of the slag can easily be explained by a contribution of charcoal ash (Tylecote et al. 1977: 310-1), and it is thus likely that they do not result from an intentional addition of flux (contra Cattoi et al. 2000, 2001).

Until now the possibility has been neglected that the slag was recycled as a flux in CA-EBA Trentino-Alto Adige/ Südtirol. The gangue material supplied several compounds, some of which having 'fluxing' effects: silica, aluminium oxide, potassium oxide, calcium oxide, magnesium oxide and, to some extent, iron oxide. It is clear from the pseudoternary diagram (Fig. 7) that the aluminium oxide content, highest in the chloritic rock fragments, played an important role in the melting system, pulling the liquid regions of the slag into the low-melting but steeply inclined iron-cordierite trough. Technical ceramic can be a source of aluminium oxide in slag, but these slags were never in contact with ceramic and must have formed in a bed of charcoal. There is no evidence that ceramics may have influenced in the composition of the slag. Saturation of silica and aluminium oxide and the deficiency of iron oxide $(\mathrm{FeO})$ controlled the slag melting temperature. It is traditionally thought that in the so-called Eibner Process, the sulphides, being rich in iron, would oxidise during roasting and smelting and supply a flux for the silicates, but in these slags, the oxidation of iron-bearing sulphides is not in an advanced stage. Most of the sulphides trapped in the gangue are not associated with iron oxides, and in the slag as well as the matte layers on the bottoms of the slag cakes, the sulphides are still iron rich, i.e. chalcopyrite and pyrrhotite.

In order to flux the system, a material rich in iron oxide $(\mathrm{FeO})$ would have been most beneficial. In describing the Himalayan copper smelting process, Blanford (1861) does not mention the addition of a flux, but Anfinset (2001:50-7) mentions the addition of old slag to accelerate the smelting process. Herdits (1997: 40-41) noted pieces of semi-smelted platy slag in a slag cake from the Brennerwald smelting site at the Mitterberg (Salzburg, Austria),

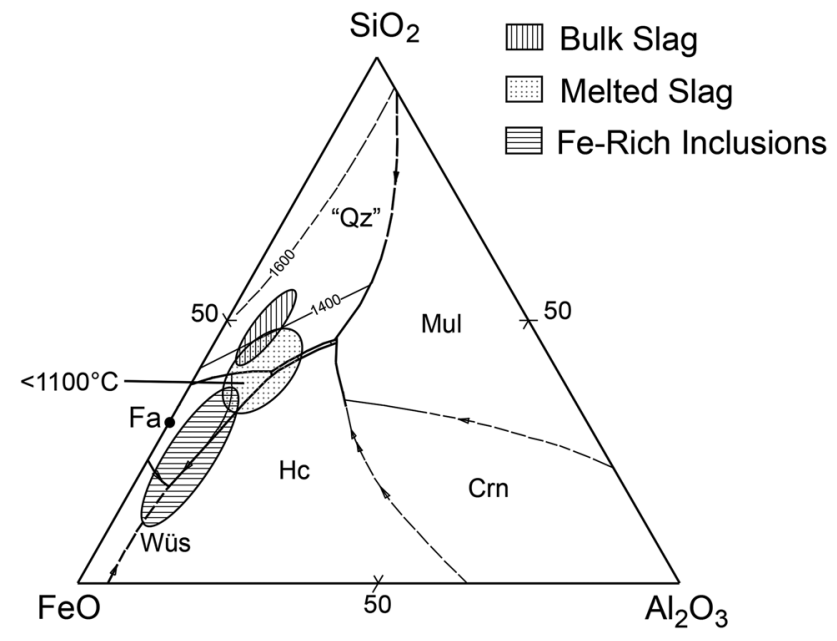

Fig. 7 Pseudo-ternary diagram $\mathrm{SiO}_{2}-\mathrm{Al}_{2} \mathrm{O}_{3}-(\mathrm{FeO}+\mathrm{MgO}+\mathrm{CaO}+$ $\mathrm{MnO}+\mathrm{ZnO}$ ) adapted from the Slag Atlas (Verein Deutscher Eisenhüttenleute 1981: 11, Fig. 3.183). The theoretical melting temperatures of the bulk slag steeply incline because of excessive silica, significant amounts of which remain unmelted in the slag. The melted parts of the slag consisting of primarily glass and fayalite conform to the lowest melting temperature region and centre at the juncture of olivine with the quartz-hercynite-iron cordierite trough, which is the lowest area in the entire system. Alternatively, the iron-rich agglomerations containing wüstite and/or magnetite inclusions follow the slope of the wüstite trough. Abbreviations: Crn, corundum; Fa, fayalite; Hc, hercynite; Mul, mullite; 'Qz', quartz; Wüs, wüstite. The ellipses represent actual analyses carried out by the authors and indicate the distribution of SEM-EDS analyses. Bulk analyses represent the average composition of each of the seven slags (multiple $\mathrm{mm}^{2}$ area analyses of powdered and homogenised slag). The glass ellipse represents the average glass composition of each of the seven slags (comprised of 39 analyses of inclusion-free areas). The iron-rich areas represent 29 area analyses from the seven different slags

which he interpreted as recycling of slag to help melt silica-rich rock. It has been suggested for Late Bronze Age copper production in Trentino following the same line of reasoning (Hauptmann 2020: 236, 314). Two types of slag are used as fluxes in Nepal, but Anfinset (2001: 50-51) notes that the last slag layer from the previous smelt (by which he seems to mean the matte conversion slag) is considered to be necessary for a successful smelt. It would make sense that the slag from the second smelting step to produce metallic copper (matte conversion) was collected and was re-used in the first smelting step (matte smelting) to help smelt the silica-rich gangue of the ore. During the matte conversion process, both sulphur and iron are oxidised, and the iron oxides are then absorbed in a silicate slag, forming a platy slag, or Plattenschlacke, which is iron-rich and fully liquefied at smelting temperatures. Some of the inclusions we observed resembling iron-rich slag, such as those containing globular and dendritic iron oxides and metallic copper prills, may in fact be remnants of intentional slag flux, though it was not possible to 
conclusively prove this. As we have seen, virtually all the slag found in CA/EBA contexts in Trentino-Alto Adige/ Südtirol region, are coarse, with platy slags only reported as present in small numbers at Gudon, Montesei di Serso, Riparo Marchi, Romagnano Loch and Romagnano Angeli, and a glassy slag at La Vela di Valbusa (Table 1). Rather than arguing that matte conversion, a vital step in the copper production process, was not practised (which would mean no copper metal), the relative absence of platy slag may be an indication of the re-use of slag as a flux in the ore smelting stage. It is possible that this rarity of platy slags and indeed their absence on most sites (13/19, cf. Table 1) indicates that the two stages of matte production and matte conversion were spatially separated, but it is striking that no evidence for sites that were specialised in matte conversion (which would be evidenced by large amounts of platy rather than coarse slag) have been found to date. We would ask why the two stages of smelting would be undertaken at two different places: certainly, there is no evidence for different specialists, and the scale of production is not sufficient to warrant such a strategy. We therefore prefer the more obvious explanation, which is evidenced in our study, that the platy slags were mostly recycled as flux.

It is likely, however, that the creation of a fully liquid slag in the first smelting stage was not desired, but rather the intention was to fuse the waste rock together so that it could be lifted from the matte, which was liquid, as described by Anfinset (2001: 53, Fig. 14) in Nepal and Blanford (1861: 390) in Sikkim. Lifting out the fused slag cake would enable the continuation of the smelting process by allowing the further charging of ore to the hot furnace, thus considerably raising efficiency (Fig. 8). Once a certain amount of matte accumulated in the furnace, the matte could be left to cool to be processed and converted to copper in subsequent production steps. The practice of lifting the slag from the furnace is attested by marks left by (presumably wooden) implements noted by ReitmaierNaef (2019: 239-240, Figs. 2 \& 3) on the underside of Late Bronze Age/Early Iron Age copper smelting slags from the Oberhalbstein (Grisons, Switzerland), and the use of a wooden pole to poke and maybe lift large slag cakes is evidenced in the later Bronze Age at the Mitterberg (Fig. 9; Klose 1918: II.30, Fig. 39). In our case, much smaller, finger-width, wooden sticks have been used to stir or test the consistency of the slag by insertion at an oblique angle into the upper surface of some of the slags (VB1, VB2, VB5; Fig. 8). Faint finger-width channels and compressed folds and bubbles can be seen on some slag cakes (VB1, VB2, VB5, VB6, VB8, VB10); generally they are only visible on the cakes that are mostly complete. These likely attest the use of wooden tongs for lifting these slags out of the furnace. The impressions

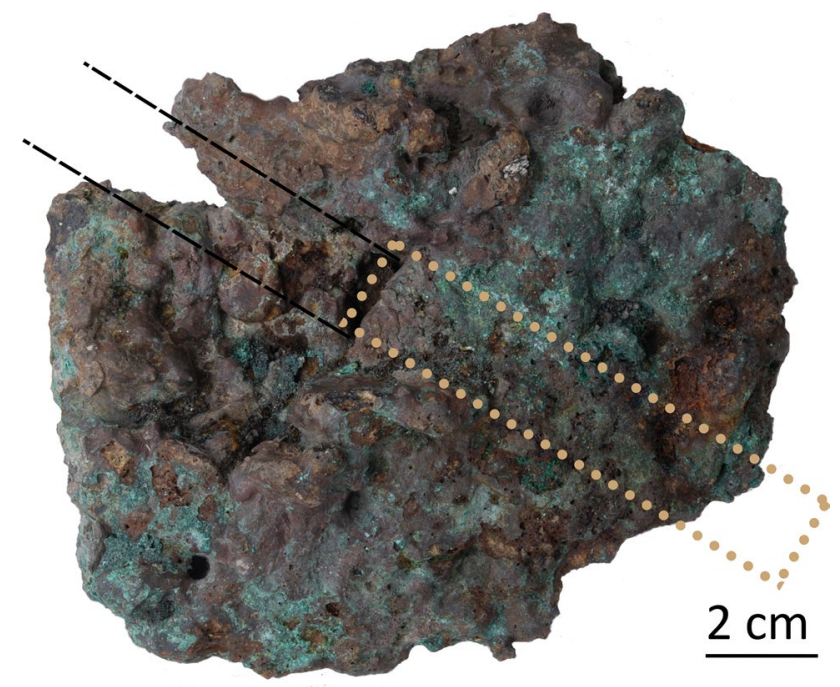

Fig. 8 Slag VB1, indicating impressions: oblique impression caused by a wooden pole (dashed line) and from the (probable) wooden tongs used from the opposite side to extract it from the furnace (dotted line). The slag was compressed on the upper surface of the cake and began to pull apart/tear in half (from the stress of lifting). The tong compressed the poking mark, showing the sequence of events

can generally only be seen on the top of the slag cake, but in one case, an impression is attested on the underside (VB5). It could be that the slag was hotter on the upper surface than the bottom because the source of heat (charcoal and airflow) was above the slag.

\section{The process reconstruction model and its implications}

We have therefore shown that smelting in the third millennium cal BC Trentino, in north-eastern Italy, did not follow the 'Timna', 'Eibner' or 'Chalcolithic copper smelting model' processes, but closely resembled ethnographically observed smelting practice in Sikkim and Nepal. We have termed this process the 'Himalaya' model. It appears to be a controlled process that was standardised in the Trentino and the adjoining Alto Adige/Südtirol.

Ore was crushed into centimetre-sized pieces and hand sorted and then smelted (matte smelting) with the addition of matte conversion slags as a flux. The slag was lifted out of the furnace using implements that were likely made of wood. This removal of slag, as documented in the Himalayas, allows multiple charges of ore to be processed in short repetition, increasing the efficiency of the process. After the final slag removal, the matte was left to cool. The matte was then roasted and re-smelted (matte conversion) to produce copper; the resulting slags were mostly reused as flux for matte smelting. 
Fig. 9 Bronze Age slag cakes from the Mitterberg, attesting the use of wooden poles to lift them out of the furnace. Photo 4 shows the original wooden pole in place; photo 3 shows a pole placed in the hole left in the slag by a pole (source: Klose 1918: Fig. 39)

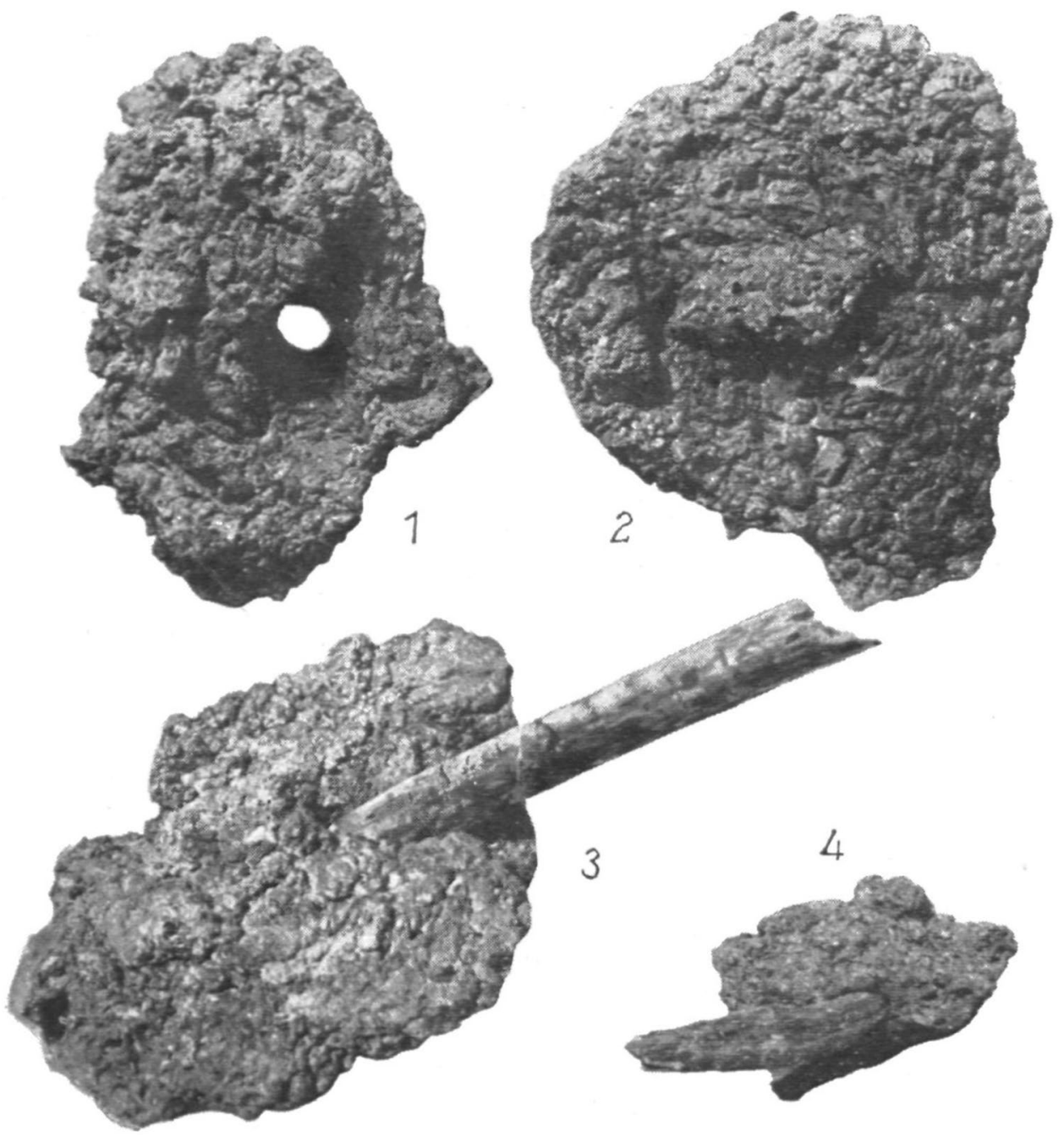

An important aspect, which is a new observation for CA and EBA Trentino, is that the semi-liquid coarse slag was nothing more than an intermediate product to facilitate the matte-smelting process. Whereas Bourgarit (2007: 5-7) suggests (implicitly from a modern viewpoint) that all early slags that did not achieve fully liquid eutectic compositions are 'immature' and 'inefficient' or indicate a 'poor mastery of the slagging process', we suggest that a fully liquid slag would have been both wasteful and a hindrance to the smelting process. In our example, it was actually advantageous that the slags could be removed in a semi-solid state, and we note that removing slag mid-smelt would have permitted multiple charges per smelt. It is important when talking about technology to consider the economics of scale. Some processes only make sense above a certain level of metal demand. Squeezing out every ounce of metal, as done with 'mature' smelting technology in shaft furnaces with low viscosity fully liquid tap slags, requires tremendous amounts of energy and a clear financial incentive to do so. Considering the low level demand and the minimal amount of labour and organisation involved, this small-scale technology may have been optimal in the context in which it was practised. The Himalayan process was still practised and economically viable until quite recently.

Previous descriptions of the Trentino slags, discussed above, have differed widely on their interpretation of the flux used. Some say quartz, some calcium oxide, others none. In this regard, it is important to look closely at the composition of the ores, gangue and host rock components and ask 'What is missing that would help the process and what is restricting the process?' We see that the slag is deprived of iron oxide, and this is the only thing that could be added to improve melting, but too much of this would have melted everything. The addition of matte conversion slag, in the right amount, may have in effect made a slag like 'ice cubes in water', aiding in the separation of liquid matte without fully liquefying all the components.

Having reconstructed the smelting process, it becomes possible to interpret the archaeological evidence found at $\mathrm{La}$ Vela di Valbusa (Fig. 2). The two roughly oval, bowl-shaped 
areas of baked clay are likely roasting beds, used for roasting matte. It is likely that the smelting furnaces were removed by quarrying prior to the rescue excavation; roughly quadrangular furnaces, made of three slabs of rock (Fig. 10), are known at other sites in the Trentino and Alto Adige/Südtirol (Gudon, Acquaviva, Riparo Gaban, Romagnano Loch, Montesei di Serso and Croz del Cius-Table 1). The internal dimensions of these furnaces vary; for example, the structure at Acquaviva is $14 \times 16 \mathrm{~cm}$, while that at Romagnano Loch is $30 \times 40 \mathrm{~cm}$. Given that the La Vela di Valbusa slag cakes were $12-14 \mathrm{~cm}$ in diameter, the furnace at the site is likely to have been closer in size to that at Acquaviva.
Although we cannot know this for certain, the fact that hot slag cakes were lifted from the furnace, just as in the Himalayan examples, makes it highly likely that multiple slag cakes were produced per smelt. Each slag cake probably represents one or two handful size charges of ore. Bringing a furnace up to $>1200{ }^{\circ} \mathrm{C}$ to smelt one handful of ore would have been exceptionally wasteful, not so if the process was continual, with cycles of ore charging and slag lifting, taking advantage of the accumulated heat. If this was the case, the technology could be as standardised and controlled as the Himalayan examples of the nineteenth and twentieth centuries.
Fig. 10 Plan and section of EBA smelting furnace, Montesei di Serso (after Perini 1989: Fig. 15a)

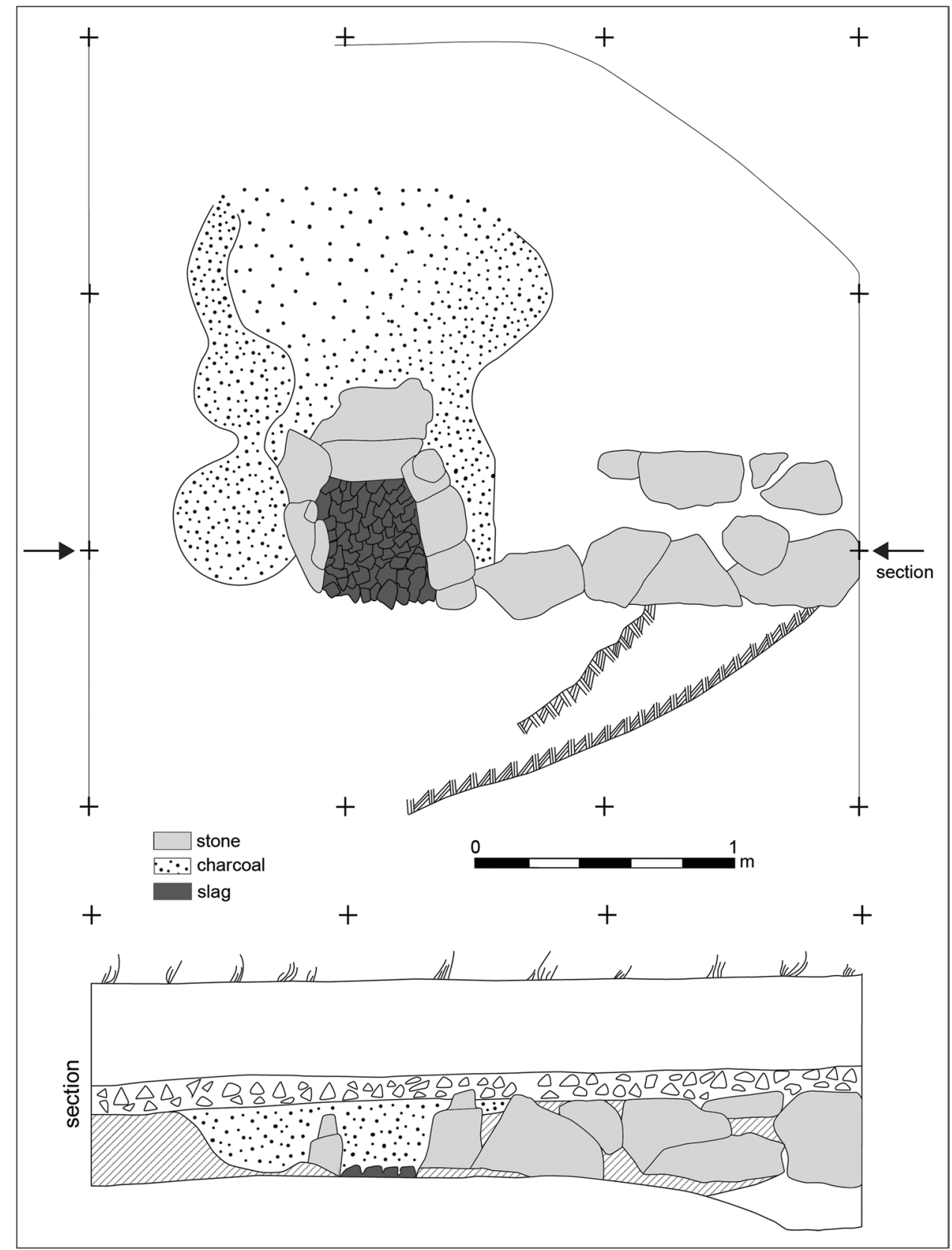




\section{Conclusions}

On the basis of observations with the naked eye and microscopy, mineralogical and elemental analyses of seven slag pieces from two rock shelters, La Vela di Valbusa and the Riparo di Monte Terlago, we were able to shed new light on the smelting of copper in the third millennium cal BC Trentino, north-eastern Italy. Our observations do not differ markedly from those of previous studies of slags from the Trentino noted above, but we have been able to interpret them in a new way. By analogy with ethnographic accounts of copper smelting in the Himalayas (Sikkim and Nepal), we were able to elucidate aspects of the smelting process, in particular the lack of ore beneficiation by crushing and washing or preliminary roasting, the use of matte conversion slags as fluxes for the first smelt (matte smelting) and the use of implements that were likely made of wood to lift the hot slags from the furnace during the smelt. The sulphide ore melts to a highly fluid sulphide matte at a much lower temperature than achieved during the smelting process, allowing it to separate from the silicates. It was the smelters' intention to produce a semi-liquid coarse slag in order to facilitate the smelting process as this enabled the slags to be removed from the smelt in a semi-solid state. The efficiency of the process would have relied on the rapid repetitions of ore charging made possible by the lifting and removal of slag during the smelt. The addition of matte conversion slag, in the right amount, aided in the separation of liquid matte without fully liquefying all the components. The slag inclusions are consistent with a chalcopyrite ore originating from mines at Calceranica or Vetriolo, as previously reported in the literature.

Supplementary Information The online version contains supplementary material available at https://doi.org/10.1007/s12520-021-01475-1.

Acknowledgements The analyses for this project were undertaken when Mark Pearce was hosted at the Deutsches Bergbau-Museum and the Ruhr-Universität Bochum, funded by a Leverhulme Trust International Academic Fellowship (IAF-2016-013). The research was generously authorised by the Ufficio Beni Archeologici of the Provincia autonoma of Trento. The authors thank Giampaolo Dalmeri and Stefano Neri (MUSE - Museo delle Scienze, Trento) for kindly providing slag from the Riparo di Monte Terlago and generously providing stratigraphical information and an unpublished radiocarbon date. The authors acknowledge Thomas Stöllner (Ruhr-Universität Bochum), Thomas Kirnbauer (Technische Hochschule Georg Agricola), Elena Silvestri, Paolo Bellintani, Elisabetta Mottes (Ufficio Beni Archeologici, Provincia autonoma di Trento), Peter Thomas, Michael Bode, Andreas Ludwig, Regina Kutz, Sandra Kruse (Deutsches Bergbau-Museum) and Umberto Tecchiati (University of Milan). Figs 1, 2 and 10 were drawn by Fabio Saccoccio (University of Nottingham). Two anonymous referees provided helpful suggestions for which we are grateful.

Funding The analyses for this project were undertaken when Mark Pearce was hosted at the Deutsches Bergbau-Museum and the RuhrUniversität Bochum, funded by the Leverhulme Trust International Academic Fellowship (IAF-2016-013).
Data availability All relevant data is included in the paper and in the Online resource (supplementary materials).

Code availability Not applicable.

\section{Declarations}

Competing interests The authors declare no competing interests.

Open Access This article is licensed under a Creative Commons Attribution 4.0 International License, which permits use, sharing, adaptation, distribution and reproduction in any medium or format, as long as you give appropriate credit to the original author(s) and the source, provide a link to the Creative Commons licence, and indicate if changes were made. The images or other third party material in this article are included in the article's Creative Commons licence, unless indicated otherwise in a credit line to the material. If material is not included in the article's Creative Commons licence and your intended use is not permitted by statutory regulation or exceeds the permitted use, you will need to obtain permission directly from the copyright holder. To view a copy of this licence, visit http://creativecommons. org/licenses/by/4.0/.

\section{References}

Addis A, Angelini I, Artioli G (2017) Late Bronze Age copper smelting in the southeastern Alps: how standardized was the smelting process? Evidence from Transacqua and Segonzano, Trentino, Italy. Archaeol Anthropol Sci 9(5):985-999

Agricola G (1912) De re metallica: translated from the first Latin edition of 1556, with biographical introduction, annotations and appendices upon the development of mining methods, metallurgical processes, geology, mineralogy \& mining law, from the earliest times to the 16th century by Herbert Clark Hoover and Lou Henry Hoover. The Mining magazine for the translators, London [Reprinted: Dover Publications, New York, 1950]

Anfinset N (2001) Social and technological aspects of mining, smelting and casting copper: an ethnoarchaeological study from Nepal. Veröffentlichen 181. Deutsches Bergbau-Museum, Bochum

Angelini I, Artioli G, Pedrotti A, Tecchiati U (2013) La metallurgia dell'età del Rame dell'Italia settentrionale con particolare riferimento al Trentino e all'Alto Adige. Le risorse minerarie e i processi di produzione del metallo. In: de Marinis RC (ed) L'età del Rame: La pianura padana e le Alpi al tempo di Ötzi. La Compagnia della Stampa Massetti Rodella editori, Brescia, pp 101-116

Angelini I, Gallo F, Artioli G, Nimis P, Tecchiati U, Baumgarten B (2012) Mineralogical and isotopic characterization of the late chalcolithic slags from Bressanone/Brixen (Northern Italy). In: Braekmans D, Honings J, Degryse P (eds) 39th International Symposium on Archaeometry: 28 May - 1 June 2012: Leuven, Belgium: Programme and Abstracts. KU Leuven, Leuven, p 65. https://ees.kuleuven.be/isa2012/scientific-programme/ISA2012 Programme_Abstracts.pdf. Accessed 6 Dec 2016

Anguilano L, Angelini I, Artioli G, Moroni M, Baumgarten B, Oberrrauch $H$ (2002) Smelting slags from Copper and Bronze Age archaeological sites in Trentino and Alto Adige. In: D'Amico C (ed) Atti del II Congresso Nazionale di Archeometria. Bologna, 29 gennaio-1 febbraio 2002. Pàtron, Bologna, pp 627-38

Artioli G, Angelini I, Tecchiati U, Pedrotti A (2015) Eneolithic copper smelting slags in the Eastern Alps: local patterns of metallurgical exploitation in the Copper Age. J Archaeol Sci 63:78-83 
Artioli G, Colpani F, Angelini I, Anguilano L (2005) Verhüttung von Erzen in Milland (Brixen, Eisacktal, BZ). Mineralogische Analysen der Schmelzshlacken / Attività metallurgiche a Millan (Bressanone, Val d'Isarco, BZ). Analisi mineralogiche delle scorie di fusione. In: Dal Ri L, Tecchiati U (eds) Abstracts. Internationale Tagung / Convegno Internazionale, Der Spätkupferzeitliche Schmelzplatz von Milland bei Brixen im Rahmen der beginnenden Metallurgie im alpinen Raum. Il sito fusorio della tarda età del Rame di Millan presso Bressanone nel quadro della prima metallurgia dell'area alpina. Bozen / Bolzano 15. Juni / Giugno 2005. Provincia Autonoma di Bolzano - Alto Adige, Rip. 13 Ufficio Beni Archeologici, Bolzano, pp 19-21

Artioli G, Angelini I, Burger E, Bourgarit D (2009) Petrographic and chemical investigations of the earliest copper smelting slags in Italy: towards a reconstruction of the beginning of copper metallurgy. In: $2^{\text {nd }}$ International Conference Archaeometallurgy in Europe 2007: Aquileia, Italy - 17-21 June 2007: Selected Papers. Associazione Italiana di Metallurgia, Milan, pp 12-20

Blanford HF (1861) Description of a native copper mine and smelting works in the Mahanuddi Valley, Sikkim Himalya. In: Percy J (ed) Metallurgy, Part 1. John Murray, London, pp 388-392

Bourgarit D (2007) Chalcolithic copper smelting. In: La Niece S, Hook D, Craddock P (eds) Metals and mines: studies in archaeometallurgy: selected papers from the conference Metallurgy: a touchstone for cross-cultural interaction, held at the British Museum 28-30 April 2005 to celebrate the career of Paul Craddock during his 40 years at the British Museum. Archetype Publications, London, pp 3-14

Bowen NL, Schairer JF (1935) The system MgO-FeO-SiO 2 . Am J Sci 29:151-217

Bronk Ramsey C (2009) Bayesian analysis of radiocarbon dates. Radiocarbon 51(1):337-360

Cattoi E, D'Amico C, Fabris S (2000) Studio petroarcheometrico di scorie di fusione della fine dell'Età del Bronzo e confronti con scorie dell'Età del Rame/Bronzo Antico in Trentino. Preistoria Alpina 31(1995):125-145

Cattoi E, D’Amico C, Gasparotto G, Girani M (2001) Petroarchaeometry of copper smelting slag in Trentino: provenance and process data. Preistoria Alpina 33(1997):151-154

Cierny J (2008) Prähistorische Kupferproduktion in den südlichen Alpen, Region Trentino Orientale. Der Anschnitt, Beiheft 22. Deutsches Bergbau-Museum, Bochum

Colpani F, Angelini I, Artioli G, Tecchiati U (2009) Copper smelting activities at the Millan and Gudon Chalcolithic sites (Bolzano, Italy): Chemical and mineralogical investigations of the archaeometallurgical finds. In: Moreau J-F (ed) Proceedings, ISA 2006: 36th International Symposium on Archaeometry, 2-6 May 2006, Quebec City, Canada, CELAT, Université Laval, Quebec, pp 367-374

Craddock PT (2009) Evidences for the earliest smelting processes in western Europe. In: 2nd international Conference: Archaeometallurgy in Europe 2007: Aquileia, Italy - 17-20 June 2007: Selected papers. Associazione Italiana di Metallurgia, Milan, pp 3-11

Craddock PT (2013) Local traditions and foreign contacts: innovation in Tartessian metallurgy. In: Camos Carrasco JM, Alvar Ezddocquerra J. (eds) Tarteso: el Emporio del metal: I Congreso Internacional Tarteso, Almuzara, Córdoba, pp 231-268

Cremante M, Storti C (2005) Metallurgische Aktivitäten in Milland: Die Untersuchung der Kupferschlacken anhand chimischer, microstruktureller und metallographischer Analysen / Attività metallurgiche a Millan: indagini su campioni di scoria e di rame attraverso analisi chimiche, analisi microstrutturali e analisi metallografiche. In: Dal Ri L, Tecchiati U (eds) Abstracts. Internationale Tagung / Convegno Internazionale, Der Spätkupferzeitliche Schmelzplatz von Milland bei Brixen im Rahmen der beginnenden Metallurgie im alpinen Raum. Il sito fusorio della tarda età del Rame di Millan presso Bressanone nel quadro della prima metallurgia dell'area alpina. Bozen / Bolzano 15. Juni / Giugno 2005. Provincia Autonoma di Bolzano - Alto Adige, Rip. 13 - Ufficio Beni Archeologici, Bolzano, pp 16-18

D'Amico C, Gasparotto G, Pedrotti A (1998) Scorie eneolitiche di Gaban e Acquaviva (Trento). Caratteri, provenienza ed estrazione del metallo. In: D'Amico C, Albore Livadie C (eds) Le Scienze della Terra e l'Archeometria. Pubblicazioni dell'Istituto Suor Orsola Benincasa. CUEN, Naples, pp 31-38

Dalmeri G, Flor E, Neri S (2011) Sondaggio con verifica stratigrafica a Riparo Monte Terlago (Monte Terlago - Terlago). Preistoria Alpina 45:327-329

Deer WA, Howie RA, Zussman J (1962) Rock-forming minerals, Vol. 3, Sheet Silicates. Longman, London

Della Casa P, Naef L, Turck R (2016) Prehistoric copper pyrotechnology in the Swiss Alps: approaches to site detection and chaîne opératoire. Quat Int 402:26-34

Doelter C (1921) Eisenchlorite. In: Doelter C (ed) Handbuch der Mineralchemie,, Vol. II, Part III. Theodor Steinkopff, Dresden/Leipzig, pp 323-355

Donaldson CH (1976) An experimental investigation of olivine morphology. Contrib Miner Petrol 57:187-195

Eibner C (1982) Kupferbergbau in Österreichs Alpen. Prähistorische Archäologie in Südosteuropa 1:399-408

Ettler V, Červinka R, Johan Z (2009) Mineralogy of medieval slags from lead and silver smelting (Bohutín, Příbram District, Czech Republic): towards estimation of historical smelting conditions. Archaeometry 51(6):987-1007

Fasani L (1990) La sepoltura e il forno di fusione de La Vela di Valbusa. Preistoria Alpina 24(1988):165-181

Faure F, Trolliard G, Nicollet C, Montel JM (2003) A developmental model of olivine morphology as a function of the cooling rate and the degree of undercooling. Contrib Miner Petrol 145:251-263

Flörke OW (1959) Über Kieselsäurekristalle in Gläsern. Glastechnische Berichte Zeitschrift für Glaskunde 32(1):1-9

Goldenberg G, Anfinset N, Silvestri E, Belgrado E, Hanning E Klaunzer M, Schneider P, Staudt M, Töchterle U (2011) Das Nepal-experiment - experimentelle Archäometallurgie mit ethnoarchäologischem Ansatz. In: Oeggl K, Goldenberg G, Stöllner T, Prast M (eds) Die Geschichte des Bergbaues in Tirol und seinen angrenzenden Gebieten. Proceedings of the 5th Milestone-Meeting SFB HiMAT, Mühlbach, 7.-10.10.2010, Innsbruck, pp 83-90

Hanning E (2012) Reconstructing Bronze Age copper smelting in the Alps: an ongoing process. Experimentelle Archäologie in Europa 11:75-86

Hauptmann A (2000) Zur frühen Metallurgie des Kupfers in Fenan/Jordanien. Der Anchnitt, Beiheft 11. Deutsches Bergbaum-Museum, Bochum

Hauptmann A (2014) The investigation of archaeometallurgical slag. In: Roberts BW, Thornton CP (eds) Archaeometallurgy in global perspective. Springer, New York, pp 91-105

Hauptmann A (2020) Archaeometallurgy - materials science aspects. Natural Science in Archaeology. Springer, New York

Hauptmann A, Pernicka E, Lutz J, Yalçın Ü (1993) Zur Technologie der frühesten Verhüttung von Kupfererzen im östlichen Mittelmeerraum. In: Frangipane M, Hauptmann H, Liverani M, Matthiae P, Mellink M (eds) Between the rivers and over the mountains: Archaeologica Anatolica et Mesopotamica Alba Palmieri Dedicata. Dipartimento di Scienze Storiche Archeologiche e Antropologiche dell'Antichità, Università di Roma "La Sapienza," Rome, pp 541-572

Hauptmann A, Rehren T, Schmitt-Strecker S (2003) Early Bronze Age copper metallurgy at Shahr-i Sokhta (Iran), reconsidered. In: Stöllner T, Körlin G, Steffens G, Cierny J (eds) Man and mining - Mensch und Bergbau: studies in honour of Gerd Weisgerber 
on occasion of his 65th birthday. Der Anschnitt, Beiheft 16. Deutsches Bergbau-Museum, Bochum, pp 197-213

Herdits H (1997) Ein bronzezeitlicher Kupfererzverhüttungsplatz in Mühlbach/Hochkönig (Salzburg). Diplomarbeit, Universität Wien

Klose O (1918) Die prähistorischen Funde vom Mitterberge bei Bischofshofen im städtischen Museum Carolino-Augusteum zu Salzburg und zwei prähistorische Schmelzöfen auf dem Mitterberge. In: Kyrle G (ed) Urgeschichte des Kronlandes Salzburg. Osterreichische Kunst-Topographie XVII. Kunstverlag Anton Schroll \& Co, Vienna, p II.1-II.40

Marzatico F (1997) L'industria metallurgica nel Trentino durante l'età del bronzo. In: Bernabò Brea M, Cardarelli A, Cremaschi M (eds) Le Terramare. La più antica civiltà padana. Electa, Milan, pp 570-576

Marzatico F (2021) Produzione metallurgica primaria e circolazione del rame nelle Alpi sud-orientali fra dati acquisiti e problemi aperti. In: Bellintani P, Silvestri E (eds) Fare Rame: la metallurgia primaria della tarda età del Bronzo in Trentino: nuovi scavi e stato dell'arte della ricerca sul campo. Provincia autonoma di Trento, Soprintendenza per i beni culturali, Ufficio beni archeologici, Trento, pp 199-221

Metten B (2003) Beitrag zur spätbronzezeitlichen Kupfermetallurgie im Trentino (Südalpen) im Vergleich mit anderen prähistorischen Kupferschlacken aus dem Alpenraum. Metalla 10(1-2):1-122

Mottes E, Bassetti M, Silvestri E (2012) The Bronze Age tumuli of Gardolo di Mezzo (Trento, Italy) in the Adige Valley. In: Borgna E, Müller Celka S (eds) Ancestral landscapes: burial mounds in the Copper and Bronze Ages (Central and Eastern Europe - Balkans - Adriatic - Aegean, 4th-2nd millennium B.C.), Proceedings of the International Conference held in Udine, May 15th-18th 2008. Travaux de la Maison de l'Orient et de la Méditerranée, Série recherches archéologiques 58, Maison de l'Orient et de la Méditerranée Jean Pouilloux, Lyon, pp 523-532

Mottes E, Bassetti M, Silvestri E, Stefan L (2014) Il sito archeometallurgico dell'età del Rame di Riparo Marchi in Valle dell'Adige (Trento). AdA: Archeologia delle Alpi 2014:39-43

Pearce M (2007) Bright Blades and Red Metal: essays on north Italian prehistoric metalwork. Specialist Studies on Italy 14. Accordia Research Institute, London

Pearce M (2020) Caves and rock shelters, burials and smelting. Metalla Sonderheft 10:19-23

Pearce M, Bellintani P, Nicolis F (2020) Frattesina and the later Bronze Age - early Iron Age metals trade: the absolute chronology of smelting sites in the Trentino-Alto Adige/Südtirol. Padusa 55(2019):67-86

Pearce M, Bellintani P, Nicolis F (2021) L'inizio della seconda fase della coltivazione del rame nel Trentino - Alto Adige/Südtirol. In: Bellintani P, Silvestri E (eds) Fare Rame: la metallurgia primaria della tarda età del Bronzo in Trentino: nuovi scavi e stato dell'arte della ricerca sul campo. Provincia autonoma di Trento, Soprintendenza per i beni culturali, Ufficio beni archeologici, Trento, pp 187-198

Perini R (1989) Testimonianze di attività metallurgica dall'Eneolitico alle fasi finali dell'Età del Bronzo nel Trentino. In: Per Giuseppe Šebesta: scritti e nota bio-bibliografica per il settantesimo compleanno. Biblioteca Comunale di Trento, Comune di Trento, Trento, pp 377-404 [reprinted 2004 in Scritti di archeologia, II parte. Provincia autonoma di Trento, Soprintendenza per i beni archeologici, Trento, pp 1115-1120]

Reimer PJ, Austin WEN, Bard E, Bayliss A, Blackwell PG, Bronk Ramsey C, Butzin M, Cheng H, Edwards RL, Friedrich M, Grootes PM, Guilderson TP, Hajdas I, Heaton TJ, Hogg AG, Hughen KA, Kromer B, Manning SW, Muscheler R, Palmer JG, Pearson C, van der Plicht J, Reimer RW, Richards DA, Scott EM, Southon JR, Turney CSM, Wacker L, Adolphi F, Büntgen U, Capano M, Fahrni SM, Fogtmann-Schulz A, Friedrich R, Köhler P, Kudsk S, Miyake F, Olsen J, Reinig F, Sakamoto M, Sookdeo A, Talamo S (2020) The IntCal20 Northern Hemisphere Radiocarbon Age Calibration Curve (0-55 cal kBP). Radiocarbon 62(4):725-757

Reitmaier-Naef L (2019) Copper smelting slag from the Oberhalbstein (Canton of Grisons, Switzerland): methodological considerations on typology and morphology. In: Turck R, Stöllner T, Goldenberg G (eds) Alpine Copper II - Alpenkupfer II - Rame delle Alpi II - Cuivre des Alpes II: new results and perspectives on prehistoric copper production. Der Anschnitt, Beiheft 42. DeutschesBergbau Museum, Bochum / Marie Leidorf, Rahden, Westphalia, pp 229-244

Rose T, Hanning E, Klein S (2021) Smelting experiments with chalcopyrite ore based on evidence from the Eastern Alps. Metalla 25(2):77-100

Rothenberg B, Blanco-Freijeiro A (1981) Studies in ancient mining and metallurgy in south-west Spain: explorations and excavations in the Province of Huelva. Metal in History 1. Institute for ArchaeoMetallurgical Studies, Institute of Archaeology, University of London, London

Schlegel H, Schüller A (1952) Das Zustandsbild Kupfer-Eisen-Schwefel. Zeitschrift für Metallkunde 43:421-428

Silvestri E, Bellintani P, Hauptmann A (2019) Bronze Age copper ore mining and smelting in Trentino (Italy). In: Turck R, Stöllner T, Goldenberg G (eds) Alpine Copper II - Alpenkupfer II - Rame delle Alpi II - Cuivre des Alpes II: new results and perspectives on prehistoric copper production. Der Anschnitt, Beiheft 42. Deutsches-Bergbau Museum, Bochum / Marie Leidorf, Rahden, Westphalia, pp 261-278

Storti C (1991) Esame delle scorie del forno di fusione de "La Vela" di Valbusa (Trento). Sibrium 21(1990-91):349-361

Tylecote RF (1987) The early history of metallurgy in Europe. Longman, London

Tylecote RF, Ghaznavi HA, Boydell PJ (1977) Partitioning of trace elements between the ores, fluxes, slags and metal during the smelting of copper. J Archaeol Sci 4:305-333

Verein Deutscher Eisenhüttenleute (1981) Slag Atlas Stahleisen MBH, Düsseldorf

Publisher's note Springer Nature remains neutral with regard to jurisdictional claims in published maps and institutional affiliations. 